\title{
The Novel Coronavirus Disease (COVID-19): A PRISMA Systematic Review and Meta-Analysis of Clinical and Paraclinical Characteristics
}

\author{
Hamidreza Hasani $\left(\mathbb{D},{ }^{1,2}\right.$ Shayan Mardi, ${ }^{3}$ Sareh Shakerian $\left(\mathbb{D},{ }^{4}\right.$ \\ Nooshin Taherzadeh-Ghahfarokhi, ${ }^{3}$ and Parham Mardi $(\mathbb{D})^{3}$ \\ ${ }^{1}$ Eye Research Center, The Five Senses Institute, Rasoul Akram Hospital, Iran University of Medical Sciences, Tehran, Iran \\ ${ }^{2}$ Department of Ophthalmology, Madani Hospital, Alborz University of Medical Sciences, Karaj, Iran \\ ${ }^{3}$ Student Research Committee, Alborz University of Medical Sciences, Karaj, Iran \\ ${ }^{4}$ Departments of Community Based Education of Health Sciences, Virtual School of Medical Education and Management, \\ Shahid Beheshti University of Medical Sciences, Tehran, Iran
}

Correspondence should be addressed to Parham Mardi; p.mardi@abzums.ac.ir

Received 7 April 2020; Revised 18 June 2020; Accepted 18 July 2020; Published 17 August 2020

Academic Editor: Valeria Cavalcanti Rolla

Copyright (c) 2020 Hamidreza Hasani et al. This is an open access article distributed under the Creative Commons Attribution License, which permits unrestricted use, distribution, and reproduction in any medium, provided the original work is properly cited.

\begin{abstract}
An outbreak of pneumonia, caused by a novel coronavirus (SARS-CoV-2), was identified in China in December 2019. This virus expanded worldwide, causing global concern. Although clinical, laboratory, and imaging features of COVID-19 are characterized in some observational studies, we undertook a systematic review and meta-analysis to assess the frequency of these features. We did a systematic review and meta-analysis using three databases to identify clinical, laboratory, and computerized tomography (CT) scanning features of rRT-PCR confirmed cases of COVID-19. Data for 3420 patients from 30 observational studies were included. Overall, the results showed that fever (84.2\%, 95\% CI 82.6-85.7), cough (62\%, 95\% CI 60-64), and fatigue (39.4\%, 95\% CI 37.2-41.6\%) are the most prevalent symptoms in COVID-19 patients. Increased CRP level, decreased lymphocyte count, and increased D-dimer level were the most common laboratory findings. Among COVID-19 patients, $92 \%$ had a positive CT finding, most prevalently ground-glass opacification (GGO) (60\%, 95\% CI 58-62) and peripheral distribution opacification (64\%, 95\% CI 60-69). These results demonstrate the clinical, paraclinical, and imaging features of COVID- 19.
\end{abstract}

\section{Background}

In December 2019, the first case of unknown origin pneumonia was identified in Wuhan, the capital city of Hubei Province. By January 7, 2020, Chinese scientists had isolated a novel virus belongs to coronaviruses family and classified it as a type of RNA virus [1].

Although the outbreak has been started from a primary zoonotic virus transmission in a large seafood market (Huanan Seafood Market), person-to-person transmission of the virus started a pandemic involving 197 countries $[2,3]$.

The clinical outcomes of SARS-CoV-2 infection are various, including asymptomatic infection, mild upper respi- ratory tract illness, severe viral pneumonia, and even death. Patients are presented with various clinical manifestations such as fever, dyspnea, and cough [4].

Initially, some studies have observed particular imaging patterns on chest radiography and computed tomography in COVID-19 patients [5]. As our knowledge increased, recent studies claimed that the sensitivity of CT scan is higher compared to rRT-PCR in the diagnosis of COVID-19 [6].

Laboratory findings are essential in order to evaluate patients' complications and triaging them [7]. Complete blood count as an easy and affordable test detects disorders such as leukopenia, anemia, and thrombocytopenia that are 


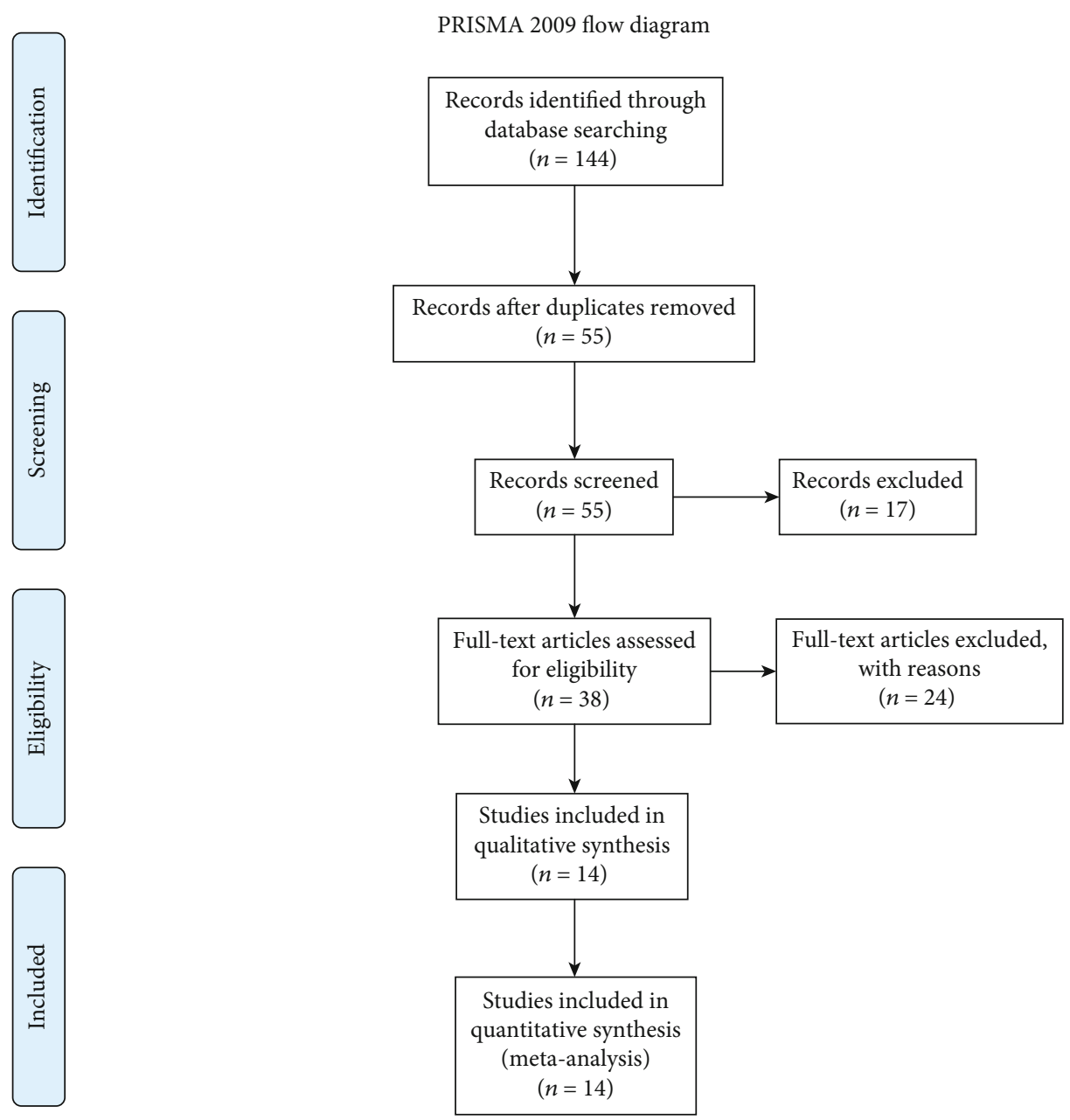

FIGURE 1: PRISMA flow chart of search, inclusion and exclusion screening, and accepted studies of the review on the clinical characteristics.

contributed to patients' prognosis [8]. In response to inflammation induced by COVID-19, acute-phase reactants may increase or decrease [9]. These factors may contribute to the patients' outcomes. This meta-analysis is aimed at measuring the most common clinical, laboratory, and imaging findings among COVID-19 patients.

\section{Methods}

2.1. Protocol. In this study, we used a protocol based on the transparent reporting of systematic reviews and metaanalysis (PRISMA) (Figures 1-3).

2.2. Eligibility Criteria. In this study, all included patients were confirmed using real-time reverse transcriptasepolymerase chain reaction (rRT-PCR). All searched articles were cross-sectional studies, reporting descriptive data, and no language restrictions were conducted. All articles published before drafting the manuscript have been included. Review articles, opinion articles, and letters not presenting original data were excluded from the analysis.

2.3. Information Sources and Search Strategy. Three systematic searches were performed using Medline/PubMed, Sco- pus, and Web of Science. Systematic search was conducted prior to March 25, 2020, and three independent researchers evaluated all papers. The search was conducted based on the following keywords, and all studies were divided in three groups: (1) For clinical characteristics group: ("clinical manifestation" AND COVID-19) or ("clinical manifestation" AND 2019-nCoV) or ("clinical manifestation" AND COVID) or ("clinical manifestation" AND Corona) or ("clinical characteristics" AND COVID-19) or ("clinical characteristics" AND 2019-nCoV) or ("clinical characteristics" AND COVID) or ("clinical characteristics" AND corona). (2) For laboratory findings group: (liver AND COVID-19) or (liver AND 2019-nCoV) or (liver AND COVID) or (liver AND Corona) or ("blood gas" AND COVID-19) or ("blood gas" AND 2019-nCoV) or ("blood gas" AND COVID) or ("blood gas” AND corona). (3) For imaging studies group: (COVID19 AND radiography) or (2019-nCoV AND radiography) or (Corona AND radiography) or (COVID AND radiography) or (COVID-19 AND radiographic) or (2019-nCoV AND radiographic) or (Corona AND radiographic) or (COVID AND radiographic) or (COVID-19 AND CT) or (2019nCoV AND CT) or (Corona AND CT) or (COVID AND CT) or (COVID-19 AND "computed tomography") or (2019-nCoV AND "computed tomography") or (Corona 


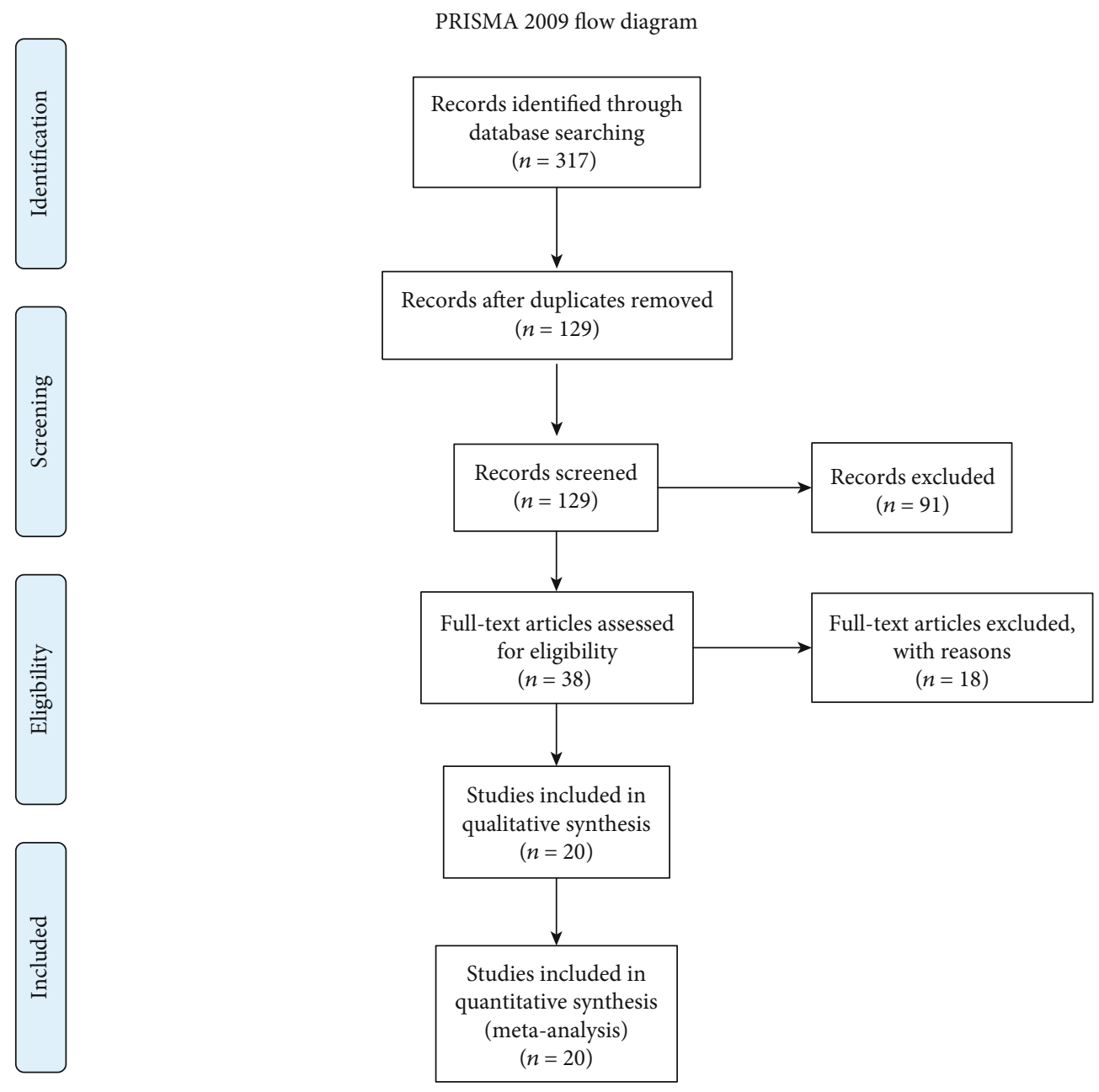

FIGURE 2: PRISMA flow chart of search, inclusion and exclusion screening, and accepted studies of the review on the imaging studies.

AND "computed tomography") or (COVID AND “computed tomography”) or (CBC AND corona) or (CBC AND COVID) or (CBC AND COVID-19) or (CBC AND 2019$\mathrm{nCoV})$.

2.4. Study Selection. In the initial search, we assessed the title and abstract, followed by a full-text evaluation based on previously described inclusion and exclusion criteria. When two articles reported one patient's characteristics, we merged all reported data and assumed as a single individual. Descriptive studies reporting clinical symptoms, laboratory, and radiological findings were used to perform a meta-analysis. The characteristics of the included studies are shown in Table 1. The modified appraisal tool for cross-sectional studies (AXIS) was used to determine the methodological quality of the research designs of the included studies (Table 2). AXIS is used to assess research papers systematically and to judge the reliability of the study being presented in the paper. It also helps in assessing the worth and relevance of the study. Studies with total scores of ten or less were excluded.

2.5. Data Collection Process and Data Items. Three independent researchers filled data extraction forms containing study type, journal, publication date, sample size, age, gender, clinical characteristics, laboratory, and radiological findings. Conflicts were resolved by another researcher.

2.6. Assessment of Methodological Quality and Risk of Bias. Publication bias was assessed with a funnel plot for the standard error and considering that the interpretation of the plot is subjective (Figures 4-6). Also, bias was quantified by using the Egger regression test.

Sensitivity analysis and adjusting for risk bias were performed by the attractive test (trim and fill method). We initially identified and trimmed the asymmetric (missing) studies, followed by estimating the unbiased summary effect. Sensitivity analysis was also performed using the "Remove-One" analysis by running the analysis with each of the studies removed. The result of the impact of each study on the pooled estimate is shown in the forest plot (Figure 7).

The percentage of total variation across studies (heterogeneity) was measured by the inconsistency index tool (I squared). The $I$ squared index measured for each of the clinical characteristics, imaging studies, and laboratory findings groups. I squared index value in the ranges of $<25 \%, 25-50 \%, 50-75 \%$, and $>75 \%$ was interpreted as 


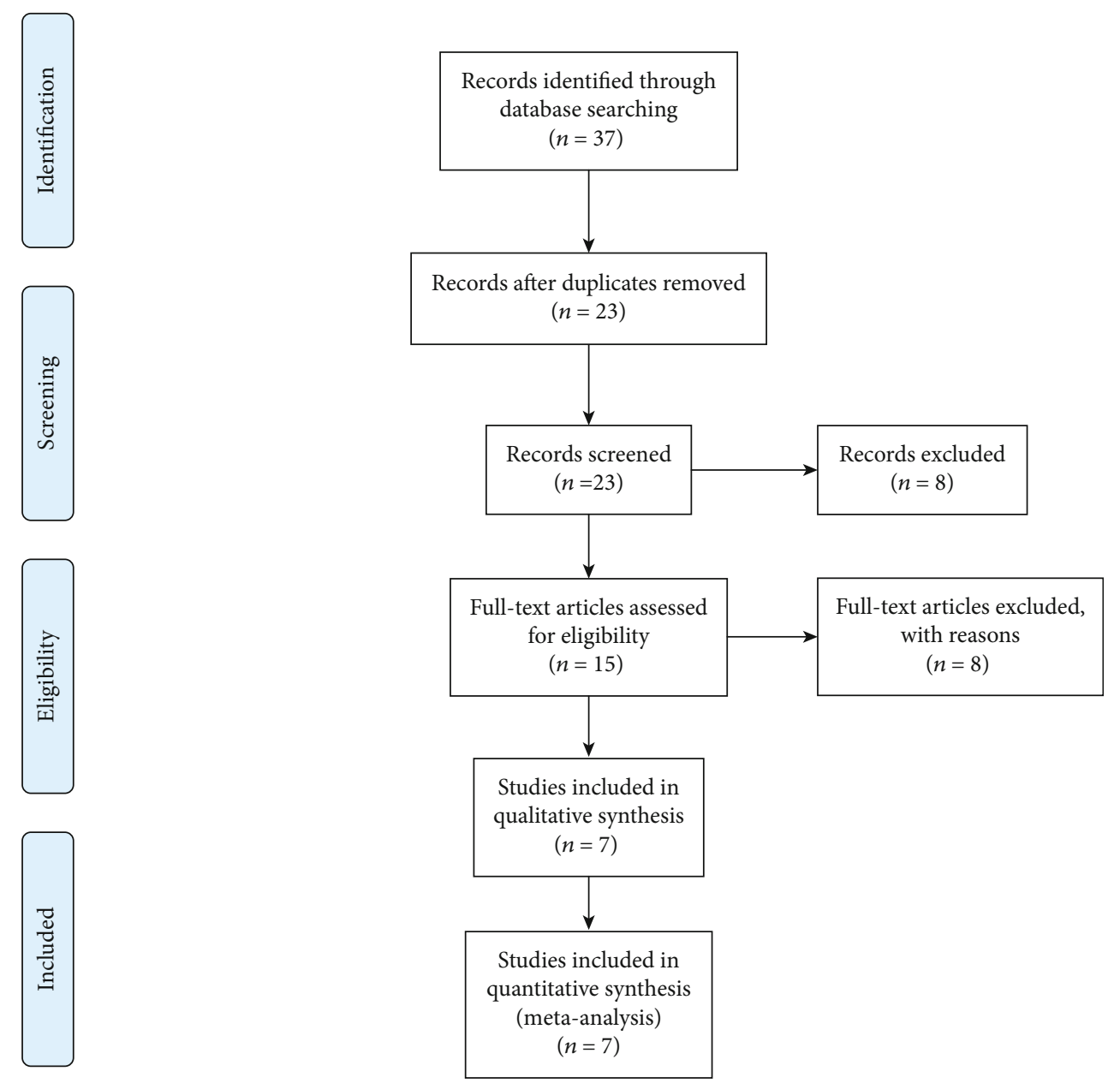

FIGURE 3: PRISMA flow chart of search, inclusion and exclusion screening, and accepted studies of the review on the laboratory findings.

low, moderate, high, and very high heterogeneity, respectively $[10]$.

We conducted a random-effects analysis because it was assumed that some of the included studies did not share a common effect size (heterogeneity). Findings in each group are summarized as forest plots in Figures 8-10.

2.7. Statistical Approach. Effect size pooled estimate for imaging and clinical data was measured based on event rate, logit event rate, and standard error.

Considering that the computational index of laboratory data was median in order to meta-analyze them in CMA v.2. software, we use the following formula:

Estimating the mean and variance from the median:

$$
\begin{gathered}
S^{2} \approx \frac{1}{12}\left(\frac{(a-2 m+b)^{2}}{4}+(b-a)^{2}\right), \\
\bar{x} \approx \frac{a+2 m+b}{4},
\end{gathered}
$$

where $m$ is the median, $a$ is the smallest value (minimum), $b$ is the largest value (maximum), and $n$ is the size of the sample [11].
The meta-analysis was performed using STATA, the software OpenMeta[Analyst], and Comprehensive MetaAnalysis Software (CMA) ve.2. Pooled estimate and their $95 \%$ confidence intervals (95\% CIs) were used to summarize the weighted effect size for each study grouping variable.

\section{Results}

3.1. Study Selection and Characteristics. Two hundred seven articles were included based on a search strategy, which are previously described (Table 1). The full text of 65 articles was evaluated after the title and abstract assessment. Twenty-four articles were excluded due to inadequate data. Finally, the meta-analysis was performed on 30 articles (three different subjects). The article's data summary is reported in Table 2. Also, demographic characteristics and comorbidities of patients participated in the included studies are demonstrated in Table 3.

In this study, we evaluate 30 articles. All papers were from China, and 3420 individual's data were evaluated. All studies were cross-sectional, and 27 variables were included.

3.2. Heterogeneity. Evaluating the heterogeneity of the studies indicated that in the clinical characteristics and imaging 
TABLE 1: Characteristics of the included studies.

\begin{tabular}{|c|c|c|c|c|c|c|c|}
\hline Row & Author & Journal & Type & Date & Country & $\begin{array}{l}\text { Sample } \\
\text { size }\end{array}$ & Reference \\
\hline \multicolumn{8}{|c|}{ Imaging } \\
\hline 1 & Fang et al. & Radiology & Cross-sectional & Feb 19 & China & 51 & {$[6]$} \\
\hline 2 & Zhao et al. & American Journal of Roentgenology & Cross-sectional & Feb 18 & China & 101 & {$[38]$} \\
\hline 3 & Shi et al. & The Lancet & Cross-sectional & Feb 24 & China & 81 & {$[40]$} \\
\hline 4 & Pan et al. & European Radiology & Cross-sectional & Feb 13 & China & 63 & {$[41]$} \\
\hline 5 & Xu et al. & $\begin{array}{c}\text { European Journal of Nuclear Medicine and Molecular } \\
\text { Imaging }\end{array}$ & Cross-sectional & Feb 28 & China & 90 & {$[42]$} \\
\hline 6 & Zhang et al. & European Respiratory Journal & Cross-sectional & Mar 25 & China & 17 & {$[43]$} \\
\hline 7 & Chen et al. & The Lancet & Cross-sectional & Jan 30 & China & 99 & {$[44]$} \\
\hline 8 & Huang & The Lancet & Cross-sectional & Feb 21 & China & 41 & {$[18]$} \\
\hline 9 & Wu et al. & Clinical Infectious Diseases & Cross-sectional & Feb 29 & China & 80 & [19] \\
\hline 10 & Guan et al. & The New England Journal of Medicine & Cross-sectional & Feb 28 & China & 1099 & {$[45]$} \\
\hline 11 & Wang et al. & Clinical Infectious Diseases & Cross-sectional & Feb 29 & China & 138 & {$[46]$} \\
\hline 12 & Yang et al. & Journal of Infection & Cross-sectional & Feb 26 & China & 149 & {$[47]$} \\
\hline 13 & Xu et al. & Journal of Infection & Cross-sectional & Feb 25 & China & 50 & {$[48]$} \\
\hline 14 & Wu et al. & Investigative Radiology & Cross-sectional & Feb 29 & China & 80 & [49] \\
\hline 15 & Li et al. & Investigative Radiology & Cross-sectional & Feb 29 & China & 83 & {$[50]$} \\
\hline 16 & Xia et al. & Pediatric Pulmonology & Cross-sectional & Mar 05 & China & 20 & {$[51]$} \\
\hline 17 & Zhang et al. & Allergy & Cross-sectional & Feb 19 & China & 140 & {$[52]$} \\
\hline 18 & Zhou et al. & American Journal of Roentgenology & Cross-sectional & Feb 16 & China & 62 & {$[53]$} \\
\hline 19 & Wang et al. & Journal of Zhejiang University & Cross-sectional & Feb 24 & China & 52 & {$[54]$} \\
\hline 20 & Yoon et al. & Korean J Radiol & Cross-sectional & Apr 21 & China & 9 & {$[55]$} \\
\hline \multicolumn{8}{|c|}{ Laboratory } \\
\hline 21 & Qian et al. & An International Journal of Medicine & Cross-sectional & Feb 21 & China & 91 & {$[56]$} \\
\hline 22 & Liu et al. & medRxiv & Cross-sectional & Feb 21 & China & 109 & {$[57]$} \\
\hline 23 & Chen et al. & medRxiv & Cross-sectional & Feb 14 & China & 21 & {$[58]$} \\
\hline 24 & Young et al. & Jama & Cross-sectional & Feb 24 & China & 18 & {$[59]$} \\
\hline 25 & Fan et al. & The Lancet & Cross-sectional & Mar 05 & China & 148 & {$[30]$} \\
\hline 26 & Wu et al. & Clinical Infectious Diseases & Cross-sectional & Feb 29 & China & 80 & {$[19]$} \\
\hline 27 & Guan et al. & New England Journal of Medicine & Cross-sectional & Feb 28 & China & 1099 & {$[45]$} \\
\hline \multicolumn{8}{|c|}{ Clinical characteristics } \\
\hline 28 & Chen et al. & The Lancet & Cross-sectional & Feb 21 & China & 99 & {$[44]$} \\
\hline 29 & $\begin{array}{l}\text { Deng and } \\
\text { Peng }\end{array}$ & Journal Clinical Medicine & Cross-sectional & Feb 14 & China & 41 & {$[60]$} \\
\hline 30 & Huang & Clinical Gastroenterology and Hepatology & Cross-sectional & Feb 21 & China & 41 & {$[18]$} \\
\hline 31 & Guan et al. & The New England Journal of Medicine & Cross-sectional & Feb 19 & China & 1099 & {$[45]$} \\
\hline 32 & Huang et al. & Travel Medicine and Infectious Disease & Cross-sectional & Feb 24 & China & 34 & {$[61]$} \\
\hline 33 & Kui et al. & Chinese Medical Journal & Cross-sectional & Feb 07 & China & 137 & {$[62]$} \\
\hline 34 & Tian et al. & Journal of Infection & Cross-sectional & Feb 27 & China & 262 & {$[63]$} \\
\hline 35 & Wang et al. & Jama & Cross-sectional & Feb 21 & China & 138 & {$[46]$} \\
\hline 36 & Wu et al. & Clinical Infectious Diseases & Cross-sectional & Feb 29 & China & 80 & {$[19]$} \\
\hline 37 & Xu et al. & $\begin{array}{c}\text { European Journal of Nuclear Medicine and Molecular } \\
\text { Imaging }\end{array}$ & Cross-sectional & Feb 28 & China & 90 & {$[42]$} \\
\hline 38 & $\begin{array}{l}\text { Xiao-Wei } \\
\text { et al. }\end{array}$ & BMJ: British Medical Journal & Cross-sectional & Feb 19 & China & 62 & {$[64]$} \\
\hline 39 & Xu et al. & Journal of Infection & Cross-sectional & Feb 25 & China & 50 & {$[48]$} \\
\hline 40 & Yang et al. & Journal of Infection & Cross-sectional & Feb 26 & China & 149 & {$[47]$} \\
\hline 41 & Zhang et al. & Allergy & Cross-sectional & Feb 19 & China & 140 & [52] \\
\hline
\end{tabular}


TABLE 2: Appraisal tool for cross-sectional studies (AXIS) scores of included studies.

\begin{tabular}{|c|c|c|c|c|c|c|c|c|c|}
\hline \multirow{2}{*}{ Row } & \multirow{2}{*}{ Author } & \multirow{2}{*}{ Date } & \multicolumn{6}{|c|}{ AXIS score } & \multirow{2}{*}{ Reference } \\
\hline & & & Introduction & Methods & Results & Discussion & Others & Total & \\
\hline 1 & Fang et al. & Feb 19 & 1 & 6 & 4 & 2 & 2 & 15 & {$[6]$} \\
\hline 2 & Zhao et al. & Feb 18 & 1 & 8 & 3 & 2 & 2 & 16 & {$[38]$} \\
\hline 3 & Shi et al. & Feb 24 & 1 & 9 & 3 & 2 & 2 & 17 & {$[40]$} \\
\hline 4 & Pan et al. & Feb 13 & 1 & 7 & 2 & 2 & 2 & 14 & {$[41]$} \\
\hline 5 & $\mathrm{Xu}$ et al. & Feb 28 & 1 & 6 & 4 & 2 & 2 & 15 & {$[42]$} \\
\hline 6 & Zhang et al. & Mar 25 & 1 & 7 & 2 & 2 & 2 & 14 & {$[43]$} \\
\hline 7 & Chen et al. & Jan 30 & 1 & 8 & 5 & 2 & 2 & 18 & {$[44]$} \\
\hline 8 & Huang & Feb 21 & 1 & 8 & 5 & 2 & 2 & 18 & {$[18]$} \\
\hline 9 & Wu et al. & Feb 29 & 1 & 6 & 2 & 2 & 1 & 12 & [19] \\
\hline 10 & Guan et al. & Feb 28 & 1 & 9 & 5 & 2 & 2 & 19 & {$[45]$} \\
\hline 11 & Wang et al. & Feb 29 & 1 & 9 & 5 & 2 & 2 & 19 & {$[46]$} \\
\hline 12 & Yang et al. & Feb 26 & 1 & 5 & 3 & 2 & 2 & 13 & {$[47]$} \\
\hline 13 & Xu et al. & Feb 25 & 1 & 6 & 4 & 2 & 2 & 15 & {$[48]$} \\
\hline 14 & Wu et al. & Feb 29 & 1 & 9 & 3 & 2 & 2 & 17 & [49] \\
\hline 15 & Li et al. & Feb 29 & 1 & 8 & 5 & 2 & 2 & 18 & {$[50]$} \\
\hline 16 & Xia et al. & Mar 05 & 1 & 5 & 2 & 2 & 2 & 12 & {$[51]$} \\
\hline 17 & Zhang et al. & Feb 19 & 1 & 6 & 2 & 1 & 2 & 12 & {$[52]$} \\
\hline 18 & Zhou et al. & Feb 16 & 1 & 5 & 4 & 2 & 2 & 14 & [53] \\
\hline 19 & Wang et al. & Feb 24 & 1 & 7 & 3 & 2 & 2 & 15 & {$[54]$} \\
\hline 20 & Yoon et al. & Apr 21 & 1 & 4 & 3 & 2 & 2 & 12 & {$[55]$} \\
\hline 21 & Qian et al. & Feb 21 & 1 & 7 & 4 & 2 & 2 & 16 & {$[56]$} \\
\hline 22 & Liu et al. & & 1 & 6 & 4 & 2 & 2 & 15 & [57] \\
\hline 23 & Chen et al. & & 1 & 5 & 2 & 2 & 2 & 12 & [58] \\
\hline 24 & Young et al. & Feb 24 & 1 & 8 & 4 & 2 & 2 & 17 & [59] \\
\hline 25 & Fan et al. & Mar 05 & 1 & 8 & 3 & 2 & 2 & 16 & {$[30]$} \\
\hline 29 & Deng and Peng & Feb 14 & 1 & 5 & 5 & 2 & 2 & 15 & {$[60]$} \\
\hline 32 & Huang et al. & Feb 24 & 1 & 5 & 3 & 2 & 2 & 13 & {$[61]$} \\
\hline 33 & Kui et al. & Feb 07 & 1 & 5 & 3 & 2 & 2 & 13 & {$[62]$} \\
\hline 34 & Tian et al. & Feb 27 & 1 & 5 & 3 & 2 & 2 & 13 & {$[63]$} \\
\hline 38 & Xiao-Wei et al. & Feb 19 & 1 & 7 & 2 & 2 & 2 & 14 & {$[64]$} \\
\hline
\end{tabular}

studies groups, the combined effect of the $I$ squared index is high $(68.43,68.53)$. While the laboratory findings groups combined effect of the $I$ squared index is considered low (6.12). I squared index for each of the outcomes is shown in Tables 4-7.

3.3. Publication Bias and Sensitivity Analysis. The Funnel plot for clinical characteristics group studies is almost symmetric confirmed by the Egger regression test (intercept $=-0.28$, $P$ value $=0.20)$. By using the random-effects model, the summary estimate and $95 \%$ confidence interval for the combined studies is $0.25(0.22,0.29)$. These findings indicated no publication bias in the clinical characteristics group (Figure 4).

The funnel plots in the imaging studies group and findings studies seem asymmetric and skewed (Figures 5 and 6). Also, the Egger regression test has indicated an intercept of 1.55 , and $P$ value of 0.01 for the laboratory findings group and an intercept of 0.94 and $P$ value of 0.04 for the imaging studies group.
In the laboratory findings group, using the randomeffects model, the point estimate and $95 \%$ confidence interval for the combined studies is $3.01(2.22,3.80)$. Using trim and fill (four trimmed studies), the imputed summary estimate is $3.30(2.30,3.38)$ (Figure 5).

In the imaging studies group, the summary estimate and 95\% confidence interval for the combined studies is 0.51 $(0.48,0.54)$. Using trim and fill, the imputed (four trimmed studies) summary estimate is $0.50(0.47,0.53)$ (Figure 6).

In conclusion, the finding of trim and fill analysis has indicated only minimal changes, which do not seem to be a threat to the validity of the effect size estimates.

Sensitivity analysis by using the "Remove-One" analysis did not show any change in the combined effect of the clinical characteristics and imaging studies groups after removing any of the studies. However, in the laboratory findings group, removing only one of the studies (Fan et al.) changed the combined effect significantly (Figure 7). The combined effect before and after removing Fan et al. study is presented in Tables 5 and 6 . 


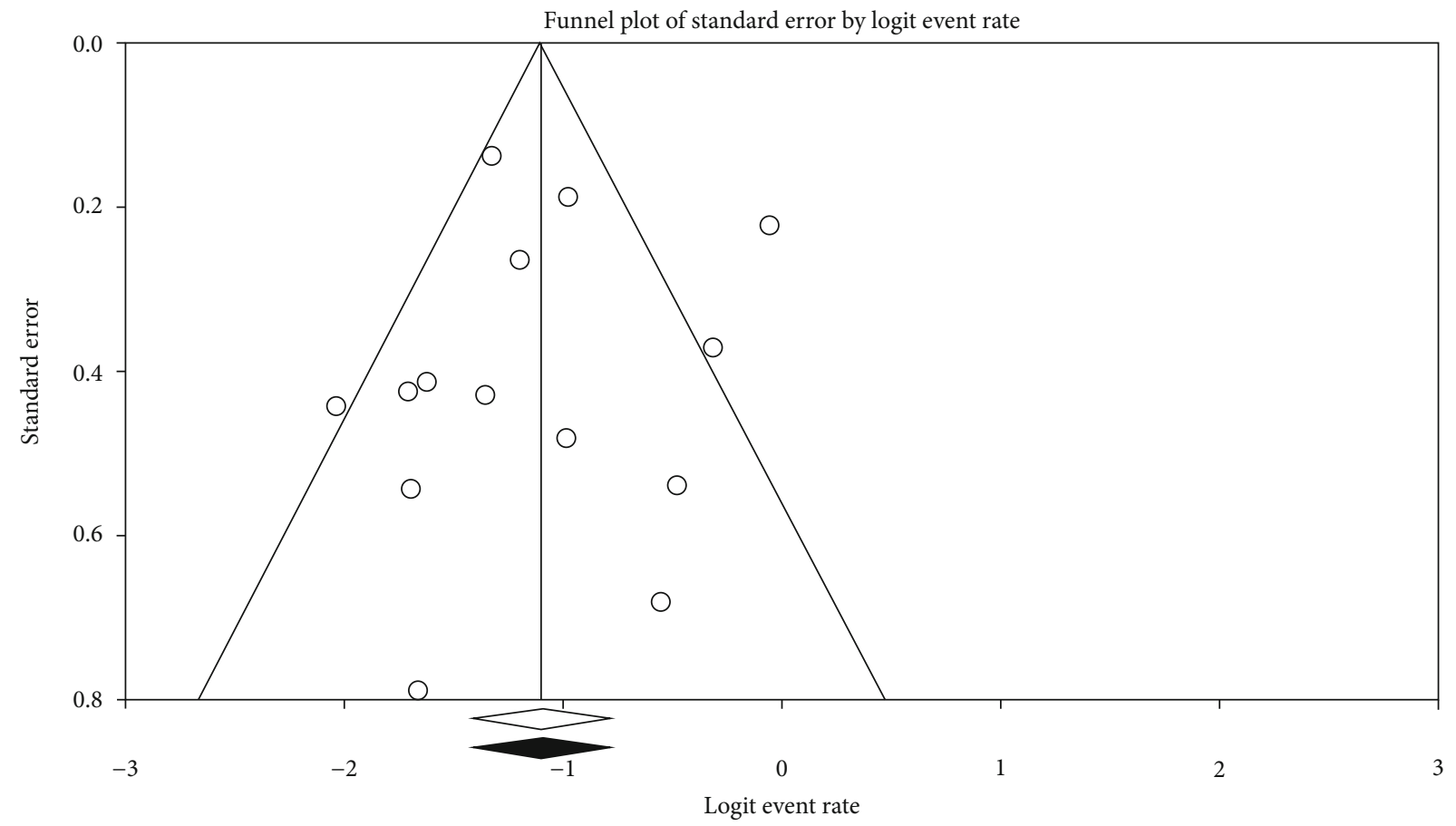

FIGURE 4: Funnel plot for clinical characteristics group studies.
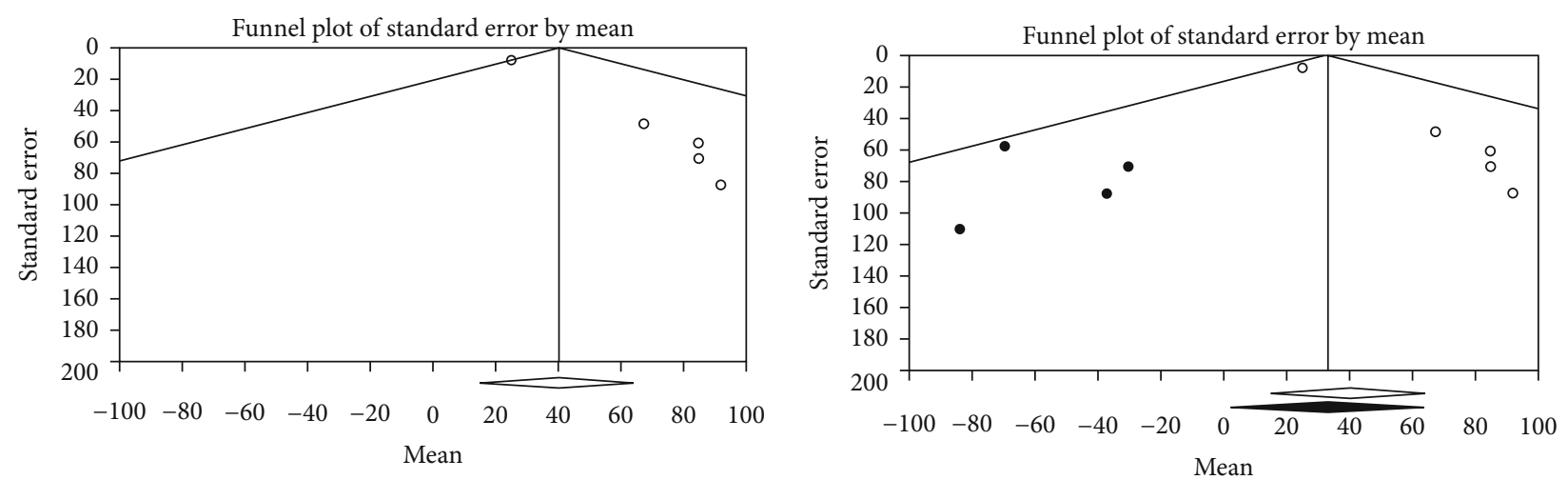

Figure 5: Funnel plots for observed studies and imputed studies (trim and fill test) of laboratory findings. The observed studies are shown as open circles, and the four imputed studies are shown as filled circles. The observed point estimate is shown as an open diamond, and the imputed point estimate is shown as a filled diamond.
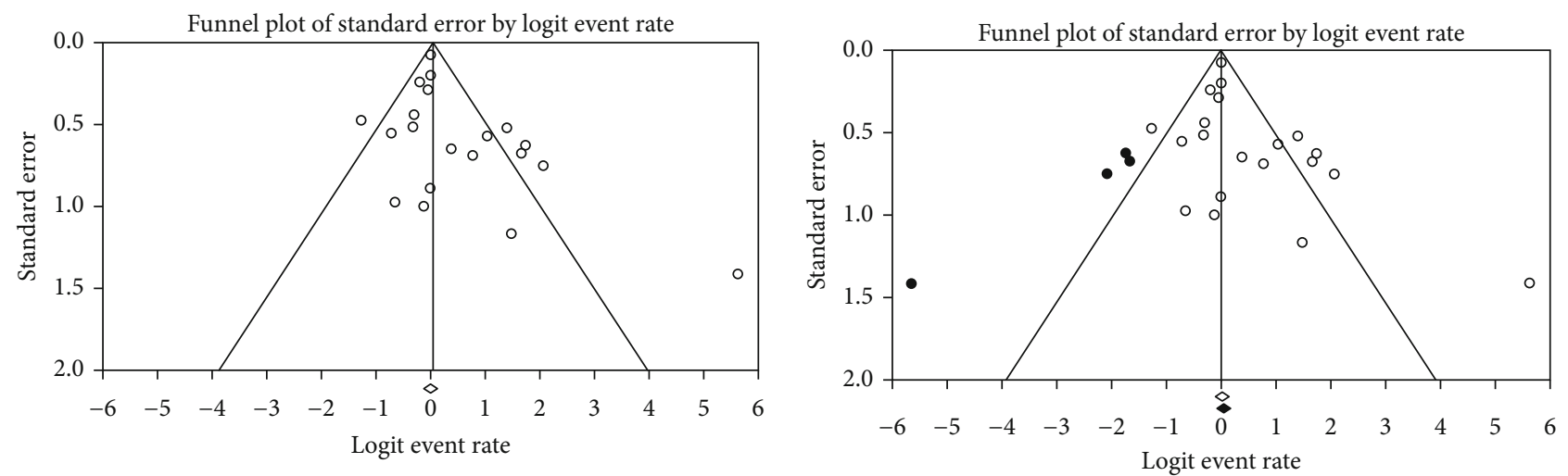

FIGURE 6: Funnel plots for observed studies and imputed studies (trim and fill test) of imaging studies. The observed studies are shown as open circles, and the four imputed studies are shown as filled circles. The observed point estimate is shown as an open diamond, and the imputed point estimate is shown as a filled diamond. 


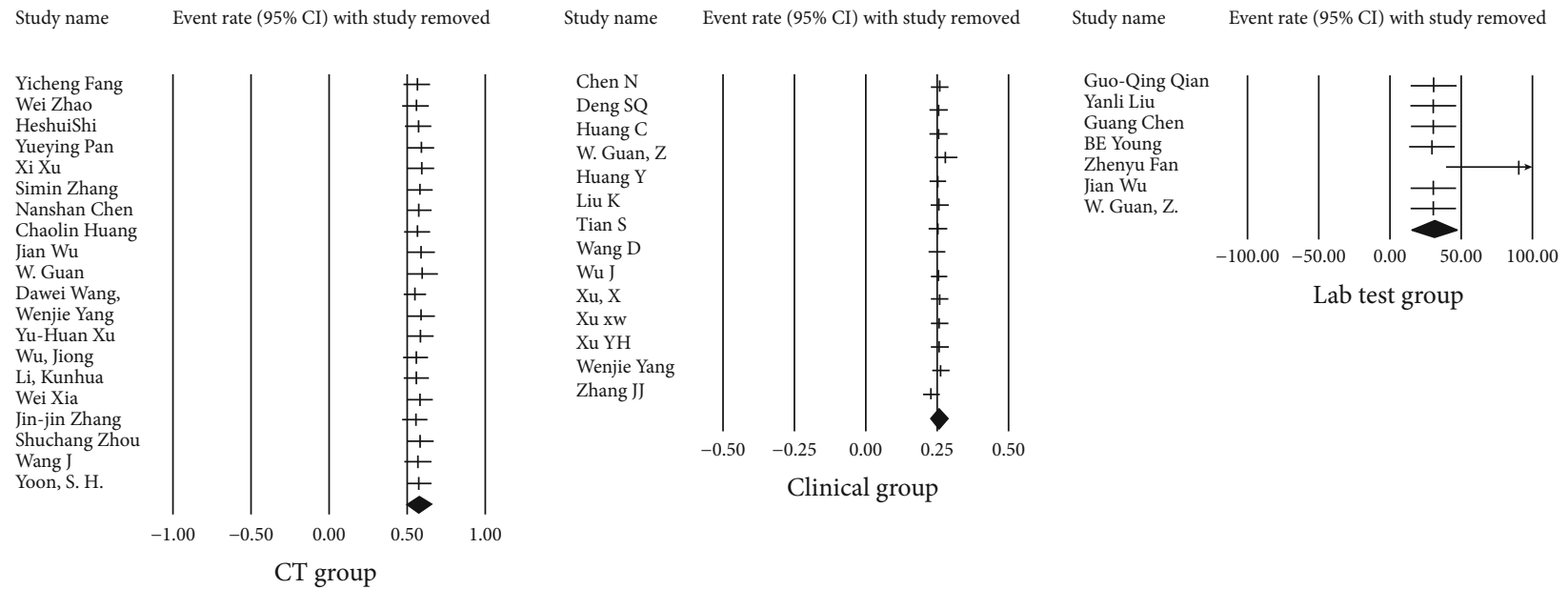

FIGURE 7: Sensitivity analysis of the meta-analysis for each of the included studies.

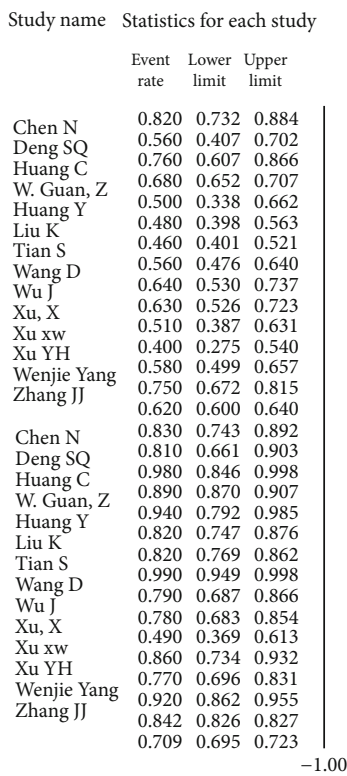

Event rate and $95 \% \mathrm{CI}$
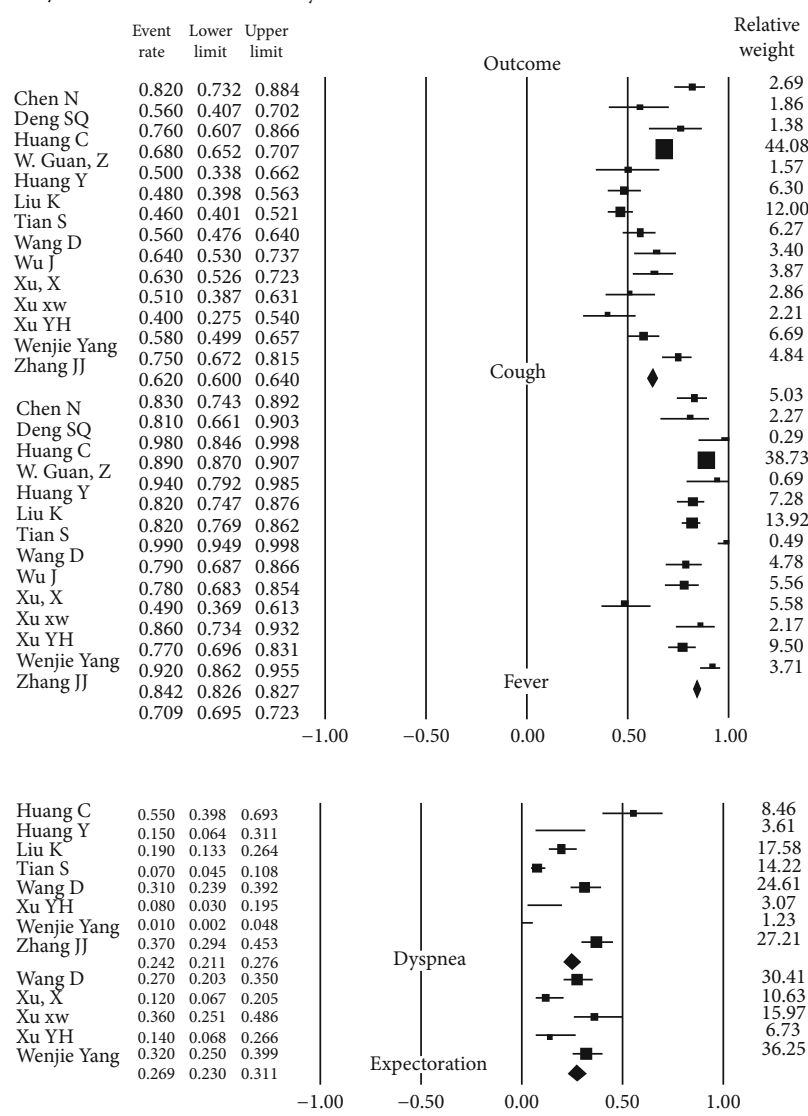

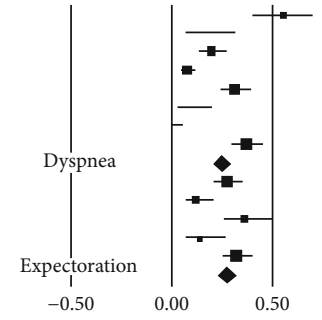

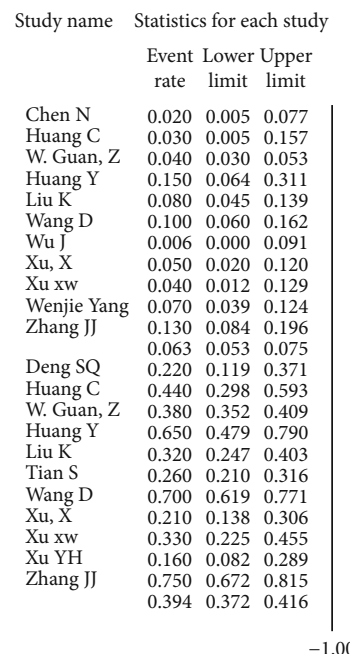

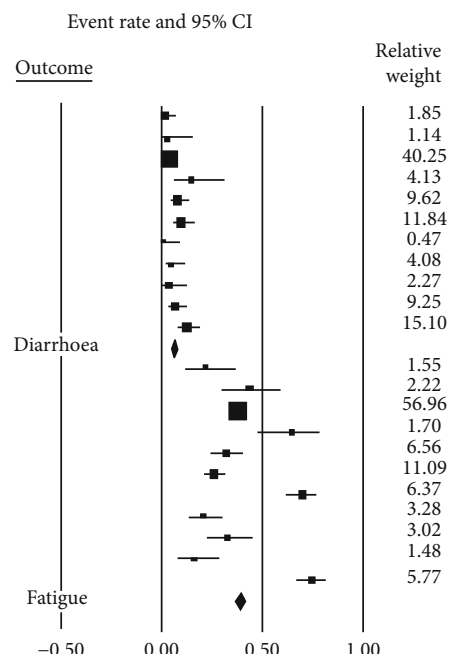

FIGURE 8: Pool prevalence forest plots of clinical manifestations.
3.4. Clinical Characteristics Group. According to clinical manifestations, fever $(84.3 \%$, 95\% CI 78.6-88.7), cough (60.1\%, 95\% CI 53.5-66.4), and fatigue (39.4\%, 95\% CI 29.1-50.8) are the most prevalent clinical symptoms among patients (Table 4) (Figure 8).

3.5. Laboratory Findings Group. Laboratory studies show increased level in following tests: CRP $(10.78 \mathrm{mg} / \mathrm{l}, 95 \% \mathrm{CI}$
6.44-15.11) with the normal range of $0-3.0 \mathrm{mg} / \mathrm{l}$, D-dimer $(567.89 \mathrm{ng} / \mathrm{ml}, 95 \%$ CI 348.15-787.62) with the normal range of $0-500 \mathrm{ng} / \mathrm{ml}, \mathrm{LDH}(258.56 \mathrm{U} / \mathrm{l}, 95 \%$ CI 206.84-310.29) with the normal range of $135-250 \mathrm{U} / \mathrm{l}$, and procalcitonin (0.17 ng/ml, 95\% CI 0.01-0.32) which is normally less than $0.05 \mathrm{ng} / \mathrm{ml}$ in a healthy individual.

Also, the level of some laboratory factors is lower than normal, such as lymphocyte $\left(1.00 * 10^{9} / 1\right.$, 95\% CI 0.73 - 

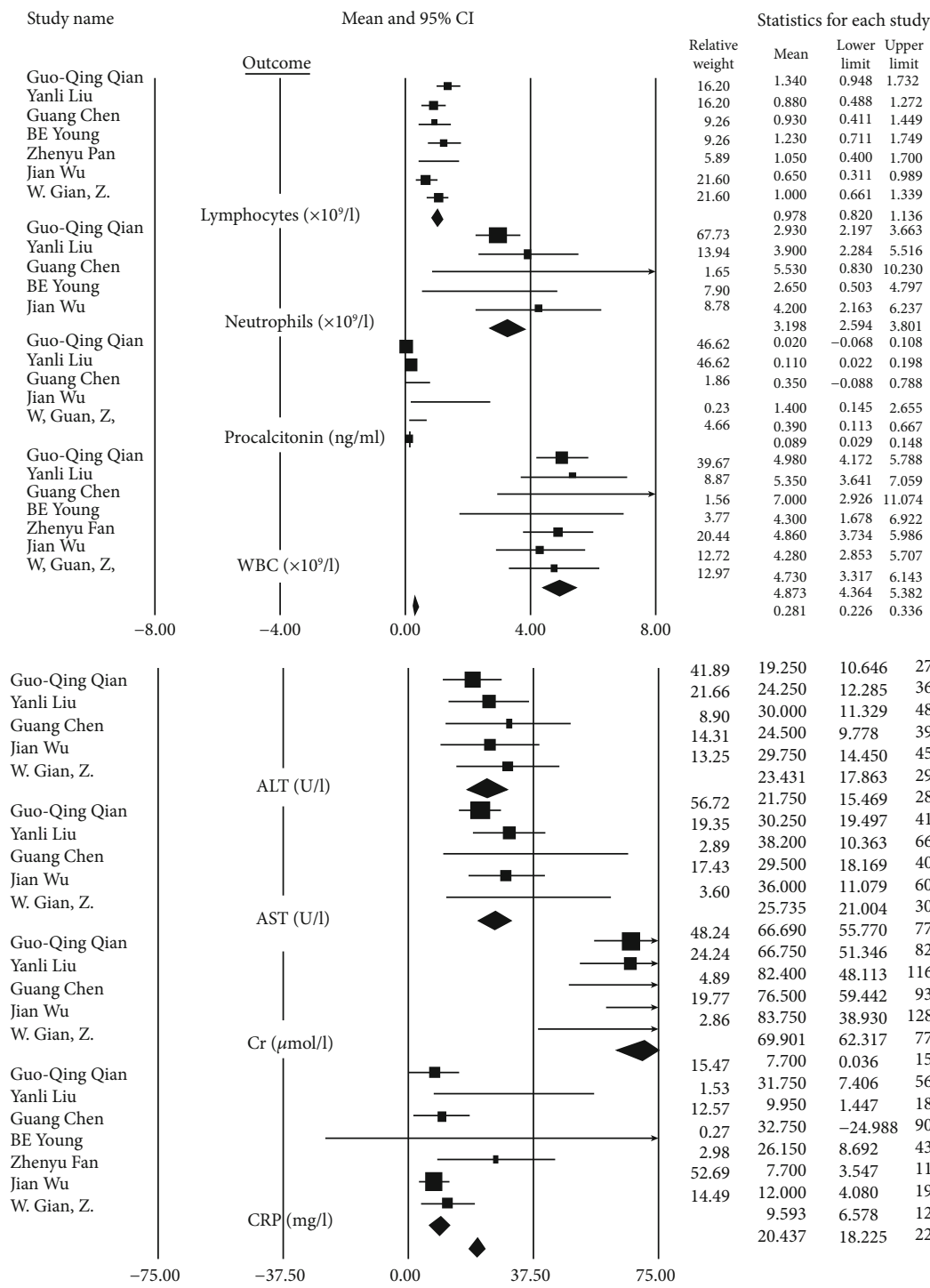

$\begin{array}{llll}41.89 & 19.250 & 10.646 & 27.854 \\ 21.66 & 24.250 & 12.285 & 36.215\end{array}$

$\begin{array}{llll}8.90 & 30.000 & 11.329 & 48.671 \\ 14.31 & 24.500 & 9.778 & 39.222\end{array}$

$\begin{array}{llll}14.31 & 24.500 & 9.778 & 39.222\end{array}$

$\begin{array}{llll}13.25 & 29.750 & 14.450 & 45.050\end{array}$

$\begin{array}{lll}23.431 & 17.863 & 29.000\end{array}$

$\begin{array}{llll}56.72 & 21.750 & 15.469 & 28.031\end{array}$

$\begin{array}{llll}19.35 & 30.250 & 19.497 & 41.003\end{array}$

$\begin{array}{llll}2.89 & 38.200 & 10.363 & 66.037\end{array}$

$\begin{array}{rrrr}17.43 & 29.500 & 18.169 & 40.831\end{array}$

$\begin{array}{llll}3.60 & 36.000 & 11.079 & 60.921\end{array}$

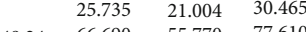

$\begin{array}{llll}48.24 & 66.690 & 55.770 & 77.610\end{array}$

$\begin{array}{llll}24.24 & 66.750 & 51.346 & 82.154\end{array}$

$\begin{array}{llll}4.89 & 82.400 & 48.113 & 116.687\end{array}$

$\begin{array}{rrrr}4.89 & 82.400 & 48.113 & 116.687 \\ 19.77 & 76.500 & 59.442 & 93.558\end{array}$

$\begin{array}{llll}2.86 & 83.750 & 38.930 & 128.570\end{array}$

\begin{tabular}{rrr}
69.901 & 62.317 & 77.485 \\
\hline
\end{tabular}

$\begin{array}{llll}15.47 & 7.700 & 0.036 & 15.364\end{array}$

$\begin{array}{llll}1.53 & 31.750 & 7.406 & 56.094\end{array}$

$\begin{array}{llll}1.53 & 9.950 & 1.447 & 18.453\end{array}$

$\begin{array}{llll}12.57 & 32.750 & -24.988 & 90.488\end{array}$

$\begin{array}{llll}0.27 & 32.750 & -24.988 & 90.488 \\ 2.98 & 26.150 & 8.692 & 43.608\end{array}$

$\begin{array}{rrrr}2.98 & 26.150 & 8.692 & 43.608 \\ 52.69 & 7.700 & 3.547 & 11.853\end{array}$

$\begin{array}{llll}14.49 & 12.000 & 4.080 & 19.920\end{array}$

$\begin{array}{rlr}9.593 & 6.578 & 12.607 \\ 20.437 & 18.225 & 22.649\end{array}$

$-75.00$

$\left.\right|_{-37.50}$

75.00
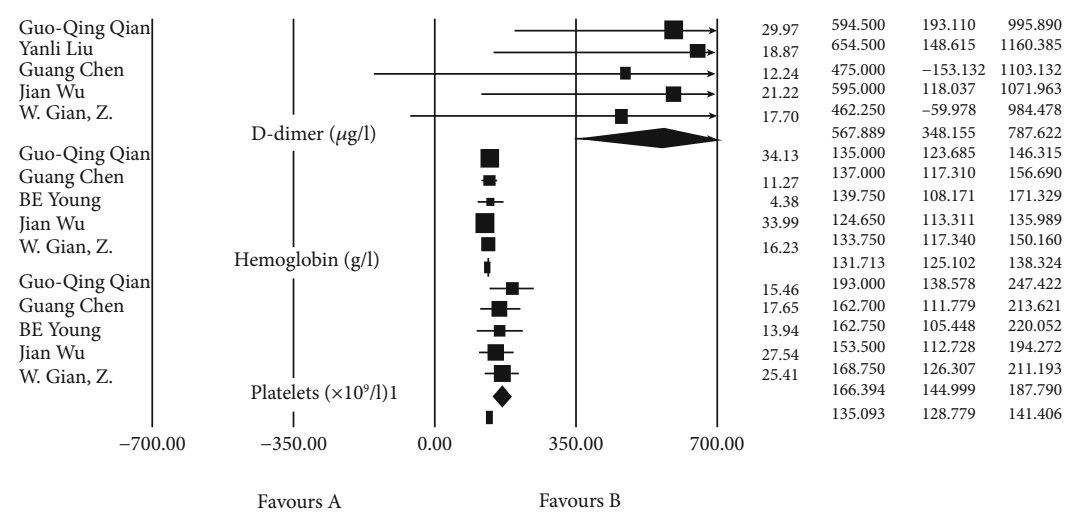

FIGURE 9: Pool prevalence forest plots of laboratory findings.

1.26) and albumin (38.61 g/l, 95\% CI 35.75-41.48) concerning the normal range of $1-4 * 10^{9} / 1$ and $40-55 \mathrm{~g} / \mathrm{l}$, respectively (Tables 5 and 6) (Figure 9).

3.6. Imaging Studies Group. Among all patients infected by SARS-CoV-2 (confirmed by RT-PCR), $85 \%$ had abnormali- ties in CT scans. In most of them, the bilateral pneumonia was dominant $(79.4 \%, 95 \%$ CI 66.9-88.1). Ground-glass opacification (GGO) $(69.8 \%, 95 \%$ CI 60.3-77.9), peripheral distribution $(66.8 \%, 95 \%$ CI 50.0-80.2), and consolidation $(37.8 \%, 95 \%$ CI 26.4-50.8) in those with CT scan results are presented (Table 7) (Figure 10). 

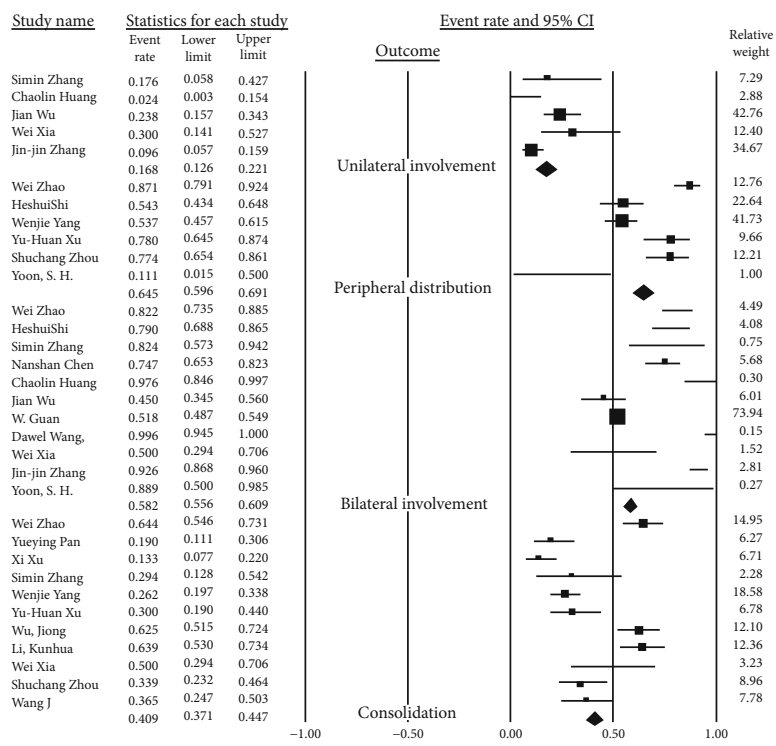

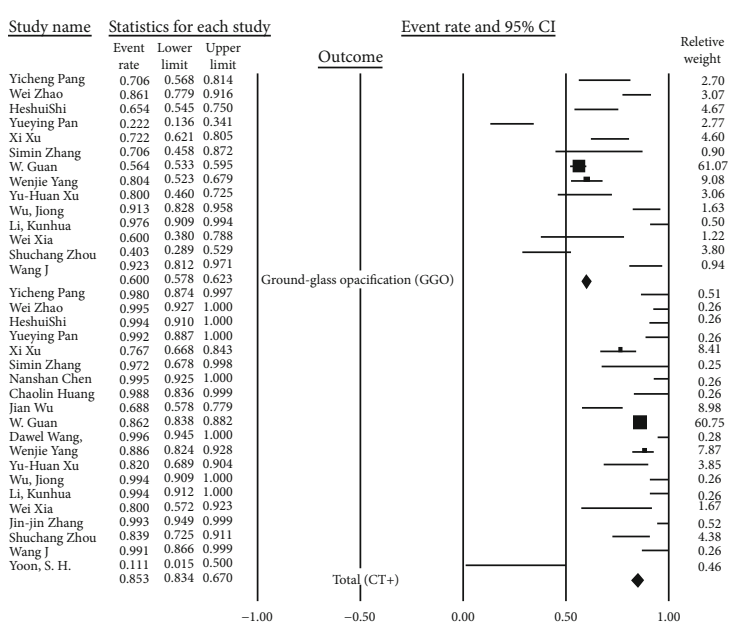

FIgURe 10: Pool prevalence forest plots of CT scan findings.

\section{Discussion}

From December 2019, more than 500,000 cases of new unknown origin pneumonia have been confirmed all over the world [12]. It was primarily known as 2019-nCov; then, WHO decided to name this novel coronavirus "SARS-CoV2" [13]. COVID-19 is a severe condition that is compromising the health condition of people in all countries worldwide [14]. Identifying the various characteristics of this infection is vital for controlling the outbreak in different countries [15]. Clinical, laboratory, and imaging findings are essential to evaluate the different aspects of infection [16]. Different outcomes of COVID-19 (from an asymptomatic infection to death) and contagiousness of this virus, even in its incubation period [17], emphasize why discovering different characteristics are crucial in controlling this pandemic.

In this systematic review and meta-analysis, we describe the most common clinical data on COVID-19 confirmed cases that were published during the first months of the outbreak. We analyzed 2422, rRT-PCR confirmed patients, for different clinical manifestations. Our findings are robust due to the pooled results after combining all the studies' data.

As expected from initial studies in China, COVID-19 patients presented predominantly with cough and fever, as well as headache, diarrhea, and fatigue, among other clinical features [18]. This was consistently found in many of the included studies $[19,20]$. Fever frequency is similar in other $\beta$-CoV-associated infections such as SARS and MERS, but studies showed that the cough frequency is higher in SARS and COVID-19 than MERS (<50\%) [21, 22]. In SARS and MERS, diarrhea is reported in about a quarter of patients, but our data shows that only 6 percent of COVID-19 patients present with diarrhea (Table 4). Our data also suggest that about 11 percent of patients are presented with headache as a symptom. Unlike SARS, which is well characterized in the two-stage clinical course of the disease [23], COVID-19 still needs further definition to identify the disease process.
Studies on epidemiological features of COVID-19 showed that about 80 percent of patients are asymptomatic or are presented with mild manifestations [24, 25], but almost all of the patients included in our study had moderate-to-severe characteristics. It seems that fever and cough are the most common clinical features among moderate-to-severe patients (Table 4).

Studies show different laboratory abnormalities in COVID-19 patients, such as hypoalbuminemia or elevated inflammatory markers [26]. However, our data suggest that C-reactive protein is the most elevated factor among infected cases (Tables 5 and 6). D-dimer, $\mathrm{LDH}$, and procalcitonin are also elevated in patients, which confirmed that measuring inflammatory markers are essential to investigate new cases [27]. Also, seven studies showed lymphopenia and albuminuria as other common laboratory findings. Data from new studies suggest lymphocytopenia or an increase in WBC as prognostic factors in COVID-19 patients. Studies on the SARS outbreak in 2003 indicate that lymphopenia, leukopenia, and thrombocytopenia, elevated levels of $\mathrm{LDH}$, alanine transaminase (ALT), AST, and creatine-kinase are the most affected laboratory findings [28].

Nevertheless, not significantly seen in COVID-19, the novel corona virus can affect the liver and other organs [29]. AST and ALT are normal in most cases, but impaired liver function tests are associated with poor prognosis and higher mortality rates [30, 31]. Coagulation function tests (such as INR) are affected in the prognosis of this infection [32]. Lymphopenia in COVID-19 patients suggests that this virus might act on lymphocytes (mainly $\mathrm{T}$ cells), but some studies suggest that B cells are also affected [26, 33].

CT scan is one of the most useful methods to diagnose the respiratory tract diseases diagnosis. CT scan high sensitivity and availability makes it one of the most common tests for lung disease screening [34, 35]. In COVID-19 patients, different results could present in the early stages of infection $[36,37]$; even some studies demonstrate that CT scan sensitivity is higher than rRT-PCR [6]. Our data shows that $92 \%$ 
TABle 3: Demographical characteristics and comorbidities of patients in the included studies.

\begin{tabular}{|c|c|c|c|c|c|c|c|c|c|c|c|c|}
\hline Row & Author & Date & $\begin{array}{l}\text { Sample } \\
\text { size }\end{array}$ & $\begin{array}{c}\text { Mean } \\
\text { age (y. old) }\end{array}$ & $\begin{array}{l}\text { Age } \\
\text { range }\end{array}$ & $\begin{array}{c}\text { Sex } \\
(\text { male })\end{array}$ & Diabetes & Hypertension & $\begin{array}{c}\text { Cardiovascular } \\
\text { disease }\end{array}$ & COPD & Malignancies & $\begin{array}{c}\text { Digestive } \\
\text { system } \\
\text { disease }\end{array}$ \\
\hline 1 & Fang et al. & Feb 19 & 51 & 45 & $39-55$ & 29 & - & - & - & - & - & - \\
\hline 2 & Zhao et al. & Feb 18 & 101 & $44 / 44$ & $17-75$ & 56 & - & - & $15 / 8$ & $4 / 9$ & - & - \\
\hline 3 & Shi et al. & Feb 24 & 81 & $49 / 5$ & $39-61$ & 42 & 12 & 15 & 10 & 11 & 5 & 9 \\
\hline 4 & Pan et al. & Feb 13 & 63 & $44 / 9$ & $31-62$ & 33 & - & - & - & - & - & - \\
\hline 5 & $\mathrm{Xu}$ et al. & Feb 28 & 90 & 50 & $18-86$ & 39 & 6 & 19 & 3 & 1 & 2 & 2 \\
\hline 6 & $\begin{array}{l}\text { Zhang } \\
\text { et al. }\end{array}$ & $\begin{array}{c}\text { Mar } \\
25\end{array}$ & 17 & $48 / 6$ & $23-74$ & 8 & - & $11 / 7$ & 5 & 11 & - & $11 / 7$ \\
\hline 7 & $\begin{array}{l}\text { Chen } \\
\text { et al. }\end{array}$ & Jan 30 & 99 & $55 / 5$ & $21-82$ & 67 & - & - & 40 & 1 & 1 & 11 \\
\hline 8 & Huang & Feb 21 & 41 & 49 & $41-58$ & 30 & 20 & 15 & 15 & 2 & 2 & 2 \\
\hline 9 & Wu et al. & Feb 29 & 80 & 46 & $18-65$ & 39 & - & - & $31 / 25$ & $1 / 25$ & $1 / 25$ & $3 / 75$ \\
\hline 10 & $\begin{array}{l}\text { Guan } \\
\text { et al. }\end{array}$ & Feb 28 & 1096 & 49 & $35-58$ & 637 & $7 / 4$ & 15 & $3 / 9$ & $1 / 1$ & $0 / 9$ & $2 / 1$ \\
\hline 11 & $\begin{array}{l}\text { Wang } \\
\text { et al. }\end{array}$ & Feb 29 & 138 & 56 & $42-68$ & 75 & $10 / 1$ & $31 / 2$ & $14 / 5$ & $2 / 9$ & $7 / 2$ & $2 / 9$ \\
\hline 12 & Yang et al. & Feb 26 & 149 & $45 / 1$ & $30-68$ & 81 & - & - & $18 / 79$ & $0 / 67$ & $1 / 34$ & $5 / 37$ \\
\hline 13 & $\mathrm{Xu}$ et al. & Feb 25 & 50 & 43 & $3-85$ & 29 & - & - & - & - & - & - \\
\hline 14 & Wu et al. & Feb 29 & 80 & 44 & $30-52$ & 42 & 5 & 5 & 1 & 4 & - & - \\
\hline 15 & Li et al. & Feb 29 & 83 & $45 / 5$ & $25-64$ & 44 & $7 / 8$ & 6 & $1 / 2$ & 6 & - & - \\
\hline 16 & Xia et al. & $\begin{array}{c}\text { Mar } \\
05\end{array}$ & 20 & 1 & $0-7$ & 13 & - & - & - & - & - & - \\
\hline 17 & $\begin{array}{l}\text { Zhang } \\
\text { et al. }\end{array}$ & Feb 19 & 135 & 57 & $25-87$ & 71 & 12 & 30 & $12 / 1$ & $2 / 8$ & - & $10 / 7$ \\
\hline 18 & $\begin{array}{l}\text { Zhou } \\
\text { et al. }\end{array}$ & Feb 16 & 62 & $52 / 8$ & $30-77$ & 39 & 6 & 6 & 1 & - & - & - \\
\hline 19 & $\begin{array}{l}\text { Wang } \\
\text { et al. }\end{array}$ & Feb 24 & 52 & - & - & - & - & - & - & - & - & - \\
\hline 20 & $\begin{array}{l}\text { Yoon } \\
\text { et al. }\end{array}$ & $\begin{array}{c}\text { Apr } \\
21\end{array}$ & 9 & 54 & - & - & - & - & - & - & - & - \\
\hline 21 & Qian et al. & Feb 21 & 91 & 50 & $36-57$ & 37 & $8 / 79$ & $16 / 48$ & $3 / 3$ & - & - & - \\
\hline 22 & Liu et al. & & 109 & 55 & $43-66$ & 59 & 11 & 33 & $6 / 4$ & $3 / 7$ & - & - \\
\hline 23 & $\begin{array}{l}\text { Chen } \\
\text { et al. }\end{array}$ & & 21 & 56 & - & 17 & $14 / 3$ & $23 / 8$ & - & - & - & - \\
\hline 24 & $\begin{array}{l}\text { Young } \\
\text { et al. }\end{array}$ & Feb 24 & 18 & 47 & $31-73$ & 9 & - & - & - & - & - & - \\
\hline 25 & Fan et al. & $\begin{array}{c}\text { Mar } \\
05\end{array}$ & 148 & 50 & $36-64$ & 73 & - & - & - & - & - & - \\
\hline 26 & Xu et al. & Feb 19 & 62 & 41 & $32-52$ & 36 & 2 & 8 & 2 & 2 & - & 11 \\
\hline 27 & $\begin{array}{l}\text { Deng and } \\
\text { Peng }\end{array}$ & Feb 14 & 41 & $55 / 5$ & $25-89$ & & $42 / 3$ & $53 / 8$ & $19 / 2$ & $19 / 2$ & - & - \\
\hline 28 & $\begin{array}{l}\text { Huang } \\
\text { et al. }\end{array}$ & Feb 24 & 34 & $56 / 24$ & $26-88$ & 14 & $11 / 8$ & $23 / 5$ & $17 / 6$ & $2 / 9$ & $8 / 8$ & $2 / 9$ \\
\hline 29 & Kui et al. & Feb 07 & 137 & 57 & $20-83$ & 61 & $9 / 5$ & $10 / 2$ & $7 / 3$ & $1 / 5$ & $1 / 5$ & - \\
\hline 30 & Tian et al. & Feb 27 & 262 & $47 / 5$ & $1-94$ & 127 & - & - & - & - & - & - \\
\hline
\end{tabular}

of rRT-PCR confirmed cases had abnormal CT scan results, which suggest CT scan as a reliable method. As seen in Table 7, CT scan meta-analysis outcomes are performed in random-effects analyses. Our meta-analysis on 15 studies showed that ground-glass opacification (GGO) and periph- eral distribution are seen on $69.8 \%$ and $66.8 \%$ of patients, respectively. $79.4 \%$ of the patients had bilateral involvements, which is contributed to poor prognosis. CT scan is useful in monitoring the treatment, and it is crucial in classifying patients and identifying who should be treated with 
TABLE 4: A meta-analysis of clinical characteristics group.

\begin{tabular}{|c|c|c|c|c|c|c|c|}
\hline \multirow{2}{*}{$\begin{array}{l}\text { Clinical group } \\
\text { Outcome }\end{array}$} & \multirow[b]{2}{*}{ Number of studies } & \multicolumn{3}{|c|}{ Effect size and 95\% confidence interval } & \multicolumn{2}{|c|}{ Test of null (2-tail) } & \multirow{2}{*}{$\begin{array}{l}\text { Heterogeneity } \\
\text { I squared }\end{array}$} \\
\hline & & Point estimate & Lower limit & Upper limit & $Z$ value & $P$ value & \\
\hline Cough & 14 & 0.601 & 0.535 & 0.664 & 2.975 & 0.003 & 87.304 \\
\hline Fever & 14 & 0.843 & 0.786 & 0.887 & 8.650 & 0.000 & 87.006 \\
\hline Headache & 12 & 0.091 & 0.070 & 0.118 & -15.933 & 0.000 & 57.760 \\
\hline Diarrhea & 11 & 0.064 & 0.043 & 0.095 & -12.258 & 0.000 & 71.281 \\
\hline Fatigue & 11 & 0.394 & 0.291 & 0.508 & -1.827 & 0.068 & 94.073 \\
\hline Dyspnea & 8 & 0.171 & 0.091 & 0.298 & -4.290 & 0.000 & 92.769 \\
\hline Expectoration & 5 & 0.239 & 0.164 & 0.334 & -4.840 & 0.000 & 77.659 \\
\hline Hemoptysis & 5 & 0.023 & 0.009 & 0.057 & -7.652 & 0.000 & 70.741 \\
\hline Shortness of breath & 5 & 0.241 & 0.151 & 0.361 & -3.898 & 0.000 & 87.758 \\
\hline Sore throat & 5 & 0.130 & 0.085 & 0.193 & -7.866 & 0.000 & 78.329 \\
\hline Muscle ache & 4 & 0.114 & 0.052 & 0.231 & -4.749 & 0.000 & 83.406 \\
\hline Nausea & 2 & 0.109 & 0.038 & 0.275 & -3.633 & 0.000 & 81.783 \\
\hline
\end{tabular}

TABle 5: Meta-analysis of laboratory findings before removing Fan et al. study.

\begin{tabular}{|c|c|c|c|c|c|c|c|c|c|}
\hline \multirow{2}{*}{$\begin{array}{l}\text { Group LAB test } \\
\text { Outcome }\end{array}$} & \multirow[b]{2}{*}{$\begin{array}{c}\text { Number of } \\
\text { studies }\end{array}$} & \multicolumn{5}{|c|}{ Effect size and 95\% confidence interval } & \multicolumn{2}{|c|}{$\begin{array}{l}\text { Test of null } \\
(2 \text {-tail })\end{array}$} & \multirow{2}{*}{$\begin{array}{c}\text { Heterogeneity } \\
\text { I squared }\end{array}$} \\
\hline & & $\begin{array}{c}\text { Point } \\
\text { estimate }\end{array}$ & $\begin{array}{c}\text { Standard } \\
\text { error }\end{array}$ & Variance & $\begin{array}{l}\text { Lower } \\
\text { limit }\end{array}$ & $\begin{array}{l}\text { Upper } \\
\text { limit }\end{array}$ & $Z$ value & $P$ value & \\
\hline $\mathrm{CRP}(\mathrm{mg} / \mathrm{l})$ & 7 & 10.78 & 2.21 & 4.89 & 6.44 & 15.11 & 4.87 & 0.0000 & 30.63 \\
\hline Lymphocytes $\left(\times 10^{9} / 1\right)$ & 7 & 1.00 & 0.13 & 0.02 & 0.73 & 1.26 & 7.48 & 0.0000 & 45.87 \\
\hline WBC $\left(\times 10^{9} / 1\right)$ & 7 & 4.87 & 0.26 & 0.07 & 4.36 & 5.38 & 18.76 & 0.0000 & 0.00 \\
\hline $\mathrm{ALT}(\mathrm{U} / \mathrm{l})$ & 5 & 23.43 & 2.84 & 8.07 & 17.86 & 29.00 & 8.25 & 0.0000 & 0.00 \\
\hline AST (U/l) & 5 & 25.84 & 2.47 & 6.08 & 21.01 & 30.68 & 10.48 & 0.0000 & 1.71 \\
\hline $\mathrm{Cr}(\mu \mathrm{mol} / \mathrm{l})$ & 5 & 69.90 & 3.87 & 14.97 & 62.32 & 77.48 & 18.06 & 0.0000 & 0.00 \\
\hline D-dimer $(\mu \mathrm{g} / \mathrm{l})$ & 5 & 567.89 & 112.11 & 12568.89 & 348.15 & 787.62 & 5.07 & 0.0000 & 0.00 \\
\hline Hemoglobin (g/l) & 5 & 131.71 & 3.37 & 11.38 & 125.10 & 138.32 & 39.05 & 0.0000 & 0.00 \\
\hline $\mathrm{LDH}(\mathrm{U} / \mathrm{l})$ & 5 & 258.56 & 26.39 & 696.51 & 206.84 & 310.29 & 9.80 & 0.0000 & 11.06 \\
\hline Neutrophils $\left(\times 10^{9} / 1\right)$ & 5 & 3.20 & 0.31 & 0.09 & 2.59 & 3.80 & 10.38 & 0.0000 & 0.00 \\
\hline Platelets $\left(\times 10^{9} / 1\right)$ & 5 & 166.39 & 10.92 & 119.17 & 145.00 & 187.79 & 15.24 & 0.0000 & 0.00 \\
\hline Procalcitonin (ng/ml) & 5 & 0.17 & 0.08 & 0.01 & 0.01 & 0.32 & 2.15 & 0.0312 & 68.47 \\
\hline Creatine kinase (U/l) & 4 & 110.18 & 19.92 & 396.72 & 71.14 & 149.22 & 5.53 & 0.0000 & 0.00 \\
\hline $\begin{array}{l}\text { Total bilirubin } \\
(\mathrm{mmol} / \mathrm{l})\end{array}$ & 4 & 8.36 & 1.08 & 1.16 & 6.25 & 10.48 & 7.76 & 0.0000 & 0.00 \\
\hline Albumin (g/l) & 3 & 38.61 & 1.46 & 2.14 & 35.75 & 41.48 & 26.41 & 0.0000 & 44.52 \\
\hline BUN (mmol/l) & 3 & 4.83 & 0.55 & 0.30 & 3.75 & 5.91 & 8.77 & 0.0000 & 0.00 \\
\hline ESR & 2 & 40.79 & 24.93 & 621.75 & -8.08 & 89.67 & 1.64 & 0.1018 & 91.15 \\
\hline Fibrinogen $(\mathrm{g} / \mathrm{l})$ & 2 & 3.21 & 0.22 & 0.05 & 2.78 & 3.64 & 14.71 & 0.0000 & 0.00 \\
\hline
\end{tabular}

aggressive treatments [38]. Other findings such as consolidation or reverse halo or atoll sign are reported in some studies [39], which were not included in our analysis.

\section{Limitations}

This review has several limitations. Few studies are available on COVID-19, and most of them are from China. Many countries such as Italy, the United States, and Iran reported several new COVID-19 patients, but data about clinical char- acteristics or laboratory findings are limited. By publishing more studies worldwide, researchers are going to get a more comprehensive understanding of COVID-19. Patients' detailed information, especially in clinical outcomes, was unavailable in most studies at the time of analysis. In this study, we used random-effects model for analysis in all three groups. In comparison to the fixed model, random model findings have wider confidence intervals and less accurate results, although heterogeneity in included studies could not be considered in the fixed model. 
TABLE 6: Meta-analysis of laboratory findings after removing Fan et al. study.

\begin{tabular}{|c|c|c|c|c|c|c|c|}
\hline \multicolumn{2}{|c|}{ Laboratory findings group (one study removed) } & \multicolumn{3}{|c|}{ Effect size and 95\% confidence interval } & \multicolumn{2}{|c|}{ Test of null (2-tail) } & \multirow{2}{*}{$\begin{array}{l}\text { Heterogeneity } \\
\text { I squared }\end{array}$} \\
\hline Outcome & Number of studies & Point estimate & Lower limit & Upper limit & $Z$ value & $P$ value & \\
\hline $\mathrm{CRP}(\mathrm{mg} / \mathrm{l})$ & 6 & 9.13 & 6.00 & 12.27 & 5.71 & 0.00 & 1.73 \\
\hline Lymphocytes $\left(\times 10^{9} / 1\right)$ & 6 & 0.99 & 0.78 & 1.20 & 9.20 & 0.00 & 37.93 \\
\hline WBC $\left(\times 10^{9} / 1\right)$ & 6 & 4.88 & 4.31 & 5.45 & 16.75 & 0.00 & 0.00 \\
\hline $\operatorname{ALT}(\mathrm{U} / \mathrm{l})$ & 5 & 23.43 & 17.86 & 29.00 & 8.25 & 0.00 & 0.00 \\
\hline AST (U/l) & 5 & 25.84 & 21.01 & 30.68 & 10.48 & 0.00 & 1.71 \\
\hline $\mathrm{Cr}(\mu \mathrm{mol} / \mathrm{l})$ & 5 & 69.90 & 62.32 & 77.48 & 18.06 & 0.00 & 0.00 \\
\hline $\mathrm{D}$-dimer $(\mu \mathrm{g} / \mathrm{l})$ & 5 & 567.89 & 348.15 & 787.62 & 5.07 & 0.00 & 0.00 \\
\hline Hemoglobin (g/l) & 5 & 131.71 & 125.10 & 138.32 & 39.05 & 0.00 & 0.00 \\
\hline $\mathrm{LDH}(\mathrm{U} / \mathrm{l})$ & 5 & 258.56 & 206.84 & 310.29 & 9.80 & 0.00 & 11.06 \\
\hline Neutrophils $\left(\times 10^{9} / 1\right)$ & 5 & 3.20 & 2.59 & 3.80 & 10.38 & 0.00 & 0.00 \\
\hline Platelets $\left(\times 10^{9} / \mathrm{l}\right)$ & 5 & 166.39 & 145.00 & 187.79 & 15.24 & 0.00 & 0.00 \\
\hline Procalcitonin (ng/ml) & 5 & 0.17 & 0.01 & 0.32 & 2.15 & 0.03 & 68.47 \\
\hline Creatine kinase (U/l) & 4 & 110.18 & 71.14 & 149.22 & 5.53 & 0.00 & 0.00 \\
\hline Total bilirubin $(\mathrm{mmol} / \mathrm{l})$ & 4 & 8.36 & 6.25 & 10.48 & 7.76 & 0.00 & 0.00 \\
\hline Albumin $(\mathrm{g} / \mathrm{l})$ & 3 & 38.61 & 35.75 & 41.48 & 26.41 & 0.00 & 44.52 \\
\hline BUN (mmol/l) & 3 & 4.83 & 3.75 & 5.91 & 8.77 & 0.00 & 0.00 \\
\hline Fibrinogen $(\mathrm{g} / \mathrm{l})$ & 2 & 3.21 & 2.78 & 3.64 & 14.71 & 0.00 & 0.00 \\
\hline
\end{tabular}

TABLE 7: A meta-analysis of imaging study outcomes.

\begin{tabular}{|c|c|c|c|c|c|c|c|}
\hline \multirow{2}{*}{$\begin{array}{l}\text { CT group } \\
\text { Outcome }\end{array}$} & \multirow[t]{2}{*}{ Number of studies } & \multicolumn{3}{|c|}{ Effect size and 95\% confidence interval } & \multicolumn{2}{|c|}{$\begin{array}{c}\text { Test of null } \\
(2 \text {-tail })\end{array}$} & \multirow{2}{*}{$\begin{array}{c}\text { Heterogeneity } \\
I \text { squared }\end{array}$} \\
\hline & & Point estimate & Lower limit & Upper limit & $Z$ value & $P$ value & \\
\hline Total (CT+) & 20 & 0.923 & 0.877 & 0.953 & 9.290 & 0.000 & 81.398 \\
\hline (1) Ground-glass opacification (GGO) & 14 & 0.698 & 0.603 & 0.779 & 3.890 & 0.000 & 90.700 \\
\hline (4) Bilateral involvement & 11 & 0.794 & 0.669 & 0.881 & 4.081 & 0.000 & 93.032 \\
\hline (5) Consolidation & 11 & 0.378 & 0.264 & 0.508 & -1.845 & 0.065 & 90.564 \\
\hline (3) Peripheral distribution & 6 & 0.668 & 0.500 & 0.802 & 1.955 & 0.051 & 88.951 \\
\hline (10) Unilateral involvement & 5 & 0.156 & 0.082 & 0.278 & -4.510 & 0.000 & 71.765 \\
\hline$(* *)$ Mixed opacity & 4 & 0.328 & 0.121 & 0.635 & -1.106 & 0.269 & 97.487 \\
\hline (11) Air bronchogram & 4 & 0.426 & 0.225 & 0.656 & -0.618 & 0.537 & 87.500 \\
\hline (6) Pleural effusion & 4 & 0.066 & 0.036 & 0.120 & -7.950 & 0.000 & 14.830 \\
\hline (7) Adjacent pleura thickening & 4 & 0.409 & 0.211 & 0.641 & -0.764 & 0.445 & 92.842 \\
\hline (12) Fibrous stripes & 3 & 0.229 & 0.056 & 0.596 & -1.486 & 0.137 & 93.828 \\
\hline (2) Lower lung predominant & 3 & 0.624 & 0.467 & 0.758 & 1.558 & 0.119 & 64.196 \\
\hline (8) Interlobular septal thickening & 3 & 0.535 & 0.359 & 0.703 & 0.379 & 0.705 & 85.123 \\
\hline 1 lobe affected & 2 & 0.207 & 0.087 & 0.417 & -2.608 & 0.009 & 83.897 \\
\hline 2 lobes affected & 2 & 0.061 & 0.032 & 0.113 & -7.927 & 0.000 & 0.000 \\
\hline 3 lobes affected & 2 & 0.105 & 0.047 & 0.220 & -4.796 & 0.000 & 57.131 \\
\hline 4 lobes affected & 2 & 0.099 & 0.060 & 0.157 & -8.135 & 0.000 & 0.000 \\
\hline 5 lobes affected & 2 & 0.394 & 0.312 & 0.483 & -2.331 & 0.020 & 18.313 \\
\hline (9) Cavitation & 2 & 0.012 & 0.002 & 0.082 & -4.350 & 0.000 & 0.000 \\
\hline Crazy-paving pattern & 2 & 0.222 & 0.067 & 0.530 & -1.786 & 0.074 & 92.080 \\
\hline Linear opacities & 2 & 0.630 & 0.555 & 0.699 & 3.372 & 0.001 & 0.000 \\
\hline
\end{tabular}

\section{Conclusion}

COVID-19 presents in the majority of cases with fever and cough. Laboratory findings such as elevated inflammatory markers can assist the diagnosis. Other laboratory indices, such as AST, ALT, or INR, are also affected in these patients. 92\% of the RT-PCR confirmed that patients have abnormalities in CT scan most frequently bilateral involvement. 
Additional research with higher sample sizes is needed in order to describe the patients' characteristics more precisely.

\section{Abbreviations}

COVID-19: Corona virus disease of 2019

rRT-PCR: Real-time reverse transcription-polymerase chain reaction

CT scan: Computed tomography scan

CI: $\quad$ Confidence intervals

CRP: $\quad$ C-reactive protein

RNA: Ribonucleic acid

SARS-CoV-2: Severe acute respiratory syndrome corona virus \#2

PRISMA: Protocol based on the transparent reporting of systematic reviews and meta-analysis

CBC: $\quad$ Complete blood count

CMA: Comprehensive meta-analysis

GGO: Ground-glass opacification

$\beta$-CoV: $\quad$ Beta coronavirus

MERS: $\quad$ Middle East respiratory syndrome

SARS: $\quad$ Severe acute respiratory syndrome

LDH: $\quad$ Lactate dehydrogenase

WBC: White blood cell

ALT: $\quad$ Alanine transaminase

AST: $\quad$ Aspartate aminotransferase

INR: International normalized ratio.

\section{Conflicts of Interest}

The authors declare that they have no competing interest regarding the publication of this paper.

\section{Authors' Contributions}

$\mathrm{HH}$ managed the group and participated in preparing the manuscript. SS participated in meta-analysis. SM and NT participated in the systematic search and substantially drafted the manuscript. PM revised the manuscript critically. All authors read and approved the final version of the manuscript.

\section{References}

[1] N. Zhu, D. Zhang, W. Wang et al., "A novel coronavirus from patients with pneumonia in China, 2019," New England Journal of Medicine, vol. 382, no. 8, pp. 727-733, 2020.

[2] C. Wang, P. W. Horby, F. G. Hayden, and G. F. Gao, "A novel coronavirus outbreak of global health concern," The Lancet, vol. 395, no. 10223, pp. 470-473, 2020.

[3] P.-I. Lee and P.-R. Hsueh, "Emerging threats from zoonotic coronaviruses-from SARS and MERS to 2019-nCoV," Journal of Microbiology, Immunology and Infection, vol. 53, no. 3, pp. 365-367, 2020.

[4] H. Chen, J. Guo, C. Wang et al., "Clinical characteristics and intrauterine vertical transmission potential of COVID-19 infection in nine pregnant women: a retrospective review of medical records," The Lancet, vol. 395, no. 10226, pp. 809$815,2020$.
[5] A. Bernheim, X. Mei, M. Huang et al., "Chest CT findings in coronavirus disease-19 (COVID-19): relationship to duration of infection," Radiology, vol. 295, no. 3, article 200463, 2020.

[6] Y. Fang, H. Zhang, J. Xie et al., "Sensitivity of chest CT for COVID-19: comparison to RT-PCR," Radiology, vol. 296, no. 2, article 200432, pp. E115-E117, 2020.

[7] World Health Organization, "Laboratory testing for coronavirus disease 2019 (COVID-19) in suspected human cases: interim guidance, 2 March 2020," 2020.

[8] Y. X. Li, W. Wu, T. Yang et al., "Characteristics of peripheral blood leukocyte differential counts in patients with COVID19," Zhonghua Nei Ke Za Zhi, vol. 59, article E003, 2020.

[9] X. Luo, W. Zhou, X. Yan et al., "Prognostic value of C-reactive protein in patients with COVID-19," 2020, https://www .medrxiv.org/content/10.1101/2020.03.21.20040360v1.

[10] J. P. Higgins, S. G. Thompson, J. J. Deeks, and D. G. Altman, "Measuring inconsistency in meta-analyses," BMJ, vol. 327, no. 7414, pp. 557-560, 2003.

[11] S. P. Hozo, B. Djulbegovic, and I. Hozo, "Estimating the mean and variance from the median, range, and the size of a sample," BMC Medical Research Methodology, vol. 5, no. 1, 2005.

[12] WHO, "Coronavirus disease 2019 (COVID-19) situation report - 69," 2020, https://www.who.int/docs/default-source/ coronaviruse/situation-reports/20200329-sitrep-69-covid-19 .pdf?sfvrsn=8d6620fa_2.

[13] A. E. Gorbalenya, S. C. Baker, R. S. Baric et al., "Severe acute respiratory syndrome-related coronavirus-the species and its viruses, a statement of the Coronavirus Study Group," 2020, https://www.biorxiv.org/content/10.1101/2020.02.07 $.937862 \mathrm{v} 1$.

[14] D. L. Heymann, N. Shindo, and WHO Scientific and Technical Advisory Group for Infectious Hazards, "COVID-19: what is next for public health?," The Lancet, vol. 395, no. 10224, pp. 542-545, 2020.

[15] E. Mahase, "Coronavirus: covid-19 has killed more people than SARS and MERS combined, despite lower case fatality rate," BMJ, vol. 368, 2020.

[16] Z. Wu and J. M. McGoogan, "Characteristics of and important lessons from the coronavirus disease 2019 (COVID-19) outbreak in China," JAMA, vol. 323, no. 13, 2020.

[17] Y. Bai, L. Yao, T. Wei et al., "Presumed asymptomatic carrier transmission of COVID-19," JAMA, vol. 323, no. 14, 2020.

[18] C. Huang, Y. Wang, X. Li et al., "Clinical features of patients infected with 2019 novel coronavirus in Wuhan, China," The Lancet, vol. 395, no. 10223, pp. 497-506, 2020.

[19] J. Wu, J. Liu, X. Zhao et al., "Clinical characteristics of imported cases of COVID-19 in Jiangsu Province: a multicenter descriptive study," Clinical Infectious Diseases, vol. 10, 2020.

[20] F. Jiang, L. Deng, L. Zhang, Y. Cai, C. W. Cheung, and Z. Xia, "Review of the clinical characteristics of coronavirus disease 2019 (COVID-19)," Journal of General Internal Medicine, vol. 35, no. 5, pp. 1545-1549, 2020.

[21] S. Meo, A. M. Alhowikan, T. al-Khlaiwi et al., "Novel coronavirus 2019-nCoV: prevalence, biological and clinical characteristics comparison with SARS-CoV and MERS-CoV," European Review for Medical and Pharmacological Sciences, vol. 24, no. 4, pp. 2012-2019, 2020.

[22] J. Guarner, "Three emerging coronaviruses in two Decades," American Journal of Clinical Pathology, vol. 153, no. 4, pp. 420-421, 2020. 
[23] J.-T. Wang, W. H. Sheng, C. T. Fang et al., "Clinical manifestations, laboratory findings, and treatment outcomes of SARS patients," Emerging Infectious Diseases, vol. 10, no. 5, pp. 818-824, 2004.

[24] D. Baud, X. Qi, K. Nielsen-Saines, D. Musso, L. Pomar, and G. Favre, "Real estimates of mortality following COVID-19 infection," The Lancet Infectious Diseases, vol. 20, no. 7, p. 773, 2020.

[25] H. Yu, J. Shao, Y. Guo et al., "Data-driven discovery of clinical routes for severity detection in COVID-19 pediatric cases," 2020, https://www.medrxiv.org/content/medrxiv/early/2020/ 03/10/2020.03.09.20032219.full.pdf.

[26] L. Tan, Q. Wang, D. Zhang et al., "Lymphopenia predicts disease severity of COVID-19: a descriptive and predictive study," 2020, https://www.medrxiv.org/content/10.1101/2020.03.01 $.20029074 \mathrm{v} 1$.

[27] J. Gong, H. Dong, S. Q. Xia et al., "Correlation analysis between disease severity and inflammation-related parameters in patients with COVID-19 pneumonia," 2020, https:// www.medrxiv.org/content/10.1101/2020.02.25.20025643v1.

[28] G. Liang, Q. Chen, J. Xu et al., "Laboratory diagnosis of four recent sporadic cases of community-acquired SARS, Guangdong Province, China," Emerging Infectious Diseases, vol. 10, no. 10, pp. 1774-1781, 2004.

[29] C. Zhang, L. Shi, and F.-S. Wang, "Liver injury in COVID-19: management and challenges," The Lancet Gastroenterology \& Hepatology, vol. 5, no. 5, pp. 428-430, 2020.

[30] Z. Fan, L. Chen, J. Li et al., "Clinical features of COVID-19related liver damage," SSRN Electronic Journal, 2020.

[31] N. Yao, S. N. Wang, J. Q. Lian et al., "Clinical characteristics and influencing factors of patients with novel coronavirus pneumonia combined with liver injury in Shaanxi region," Zhonghua gan zang bing za zhi= Zhonghua ganzangbing zazhi= Chinese Journal of Hepatology, vol. 28, 2020.

[32] T. Li, H. Lu, and W. Zhang, "Clinical observation and management of COVID-19 patients," Emerging Microbes \& Infections, vol. 9, no. 1, pp. 687-690, 2020.

[33] C. Qin, L. Zhou, Z. Hu et al., "Dysregulation of immune response in patients with Coronavirus 2019 (COVID-19) in Wuhan, China," Clinical Infectious Diseases, vol. 71, no. 15, pp. 762-768, 2020.

[34] J. R. Mathieson, J. R. Mayo, C. A. Staples, and N. L. Müller, "Chronic diffuse infiltrative lung disease: comparison of diagnostic accuracy of CT and chest radiography," Radiology, vol. 171, no. 1, pp. 111-116, 1989.

[35] R. T. Tan, R. Kuzo, L. R. Goodman, R. Siegel, G. R. Haasler, and K. W. Presberg, "Utility of CT scan evaluation for predicting pulmonary hypertension in patients with parenchymal lung disease," Chest, vol. 113, no. 5, pp. 1250-1256, 1998.

[36] M. Li, P. Lei, B. Zeng et al., "Coronavirus disease (COVID-19): spectrum of CT findings and temporal progression of the disease," Academic Radiology, vol. 27, no. 5, pp. 603-608, 2020.

[37] Z. Ye, Y. Zhang, Y. Wang, Z. Huang, and B. Song, "Chest CT manifestations of new coronavirus disease 2019 (COVID19): a pictorial review," European Radiology, vol. 30, no. 8, pp. 4381-4389, 2020.

[38] W. Zhao, Z. Zhong, X. Xie, Q. Yu, and J. Liu, "Relation between chest CT findings and clinical conditions of coronavirus disease (COVID-19) pneumonia: a multicenter study," American Journal of Roentgenology, vol. 214, no. 5, pp. 10721077, 2020.
[39] X. Li, X. Zeng, B. Liu, and Y. Yu, "COVID-19 infection presenting with CT halo sign," Radiology: Cardiothoracic Imaging, vol. 2, no. 1, article e200026, 2020.

[40] H. Shi, X. Han, N. Jiang et al., "Radiological findings from 81 patients with COVID-19 pneumonia in Wuhan, China: a descriptive study," The Lancet Infectious Diseases, vol. 20, no. 4, pp. 425-434, 2020.

[41] Y. Pan, H. Guan, S. Zhou et al., "Initial CT findings and temporal changes in patients with the novel coronavirus pneumonia (2019-nCoV): a study of 63 patients in Wuhan, China," European Radiology, vol. 30, no. 6, pp. 3306-3309, 2020.

[42] X. Xu, C. Yu, J. Qu et al., "Imaging and clinical features of patients with 2019 novel coronavirus SARS-CoV-2," European Journal of Nuclear Medicine and Molecular Imaging, vol. 47, no. 5, pp. 1275-1280, 2020.

[43] S. Zhang, H. Li, S. Huang, W. You, and H. Sun, "High-resolution computed tomography features of 17 cases of coronavirus disease 2019 in Sichuan province, China," European Respiratory Journal, vol. 55, no. 4, article 2000334, 2020.

[44] N. Chen, M. Zhou, X. Dong et al., "Epidemiological and clinical characteristics of 99 cases of 2019 novel coronavirus pneumonia in Wuhan, China: a descriptive study," The Lancet, vol. 395, no. 10223, pp. 507-513, 2020.

[45] W.-j. Guan, Z. Y. Ni, Y. Hu et al., "Clinical characteristics of coronavirus disease 2019 in China," New England Journal of Medicine, vol. 382, no. 18, pp. 1708-1720, 2020.

[46] D. Wang, B. Hu, C. Hu et al., "Clinical characteristics of 138 hospitalized patients with 2019 novel coronavirus-infected pneumonia in Wuhan, China," JAMA, vol. 323, no. 11, p. 1061, 2020.

[47] W. Yang, Q. Cao, L. Qin et al., "Clinical characteristics and imaging manifestations of the 2019 novel coronavirus disease (COVID-19):A multi-center study in Wenzhou city, Zhejiang, China," Journal of Infection, vol. 80 , no. 4, pp. 388 393, 2020.

[48] Y.-H. Xu, J. H. Dong, W. M. An et al., "Clinical and computed tomographic imaging features of novel coronavirus pneumonia caused by SARS-CoV-2," Journal of Infection, vol. 80, no. 4, pp. 394-400, 2020.

[49] J. Wu, X. Wu, W. Zeng et al., "Chest CT findings in patients with Coronavirus disease 2019 and its relationship with clinical features," Investigative Radiology, vol. 55, no. 5, pp. 257$261,2020$.

[50] K. Li, J. Wu, F. Wu et al., "The clinical and chest CT features associated with severe and critical COVID-19 pneumonia," Investigative Radiology, vol. 55, no. 6, pp. 327-331, 2020.

[51] W. Xia, J. Shao, Y. Guo, X. Peng, Z. Li, and D. Hu, "Clinical and CT features in pediatric patients with COVID-19 infection: different points from adults," Pediatric Pulmonology, vol. 55, no. 5, pp. 1169-1174, 2020.

[52] J.-j. Zhang, X. Dong, Y.-y. Cao et al., "Clinical characteristics of 140 patients infected with SARS-CoV-2 in Wuhan, China," Allergy, vol. 75, no. 7, pp. 1730-1741, 2020.

[53] S. Zhou, Y. Wang, T. Zhu, and L. Xia, "CT features of coronavirus disease 2019 (COVID-19) pneumonia in 62 patients in Wuhan, China," American Journal of Roentgenology, vol. 214, no. 6, pp. 1287-1294, 2020.

[54] J. Wang, J. Liu, Y. Wang et al., "Dynamic changes of chest CT imaging in patients with corona virus disease-19 (COVID19)," Journal of Zhejiang University (Medical Science), vol. 49 , no. $1,2020$. 
[55] S. H. Yoon, K. H. Lee, J. Y. Kim et al., "Chest radiographic and CT findings of the 2019 novel coronavirus disease (COVID19): analysis of nine patients treated in Korea," Korean Journal of Radiology, vol. 21, no. 4, pp. 494-500, 2020.

[56] G.-Q. Qian, N.-B. Yang, F. Ding et al., "Epidemiologic and clinical characteristics of 91 hospitalized patients with COVID-19 in Zhejiang, China: a retrospective, multi-centre case series," 2020, https://www.medrxiv.org/content/10.1101/ 2020.02.23.20026856v2.

[57] Y. Liu, W. Sun, L. Chen, Y. Wang, L. Zhang, and L. Yu, "Clinical characteristics and progression of 2019 novel coronavirusinfected patients concurrent acute respiratory distress syndrome," 2020, https://www.medrxiv.org/content/10.1101/ 2020.02.17.20024166v1.article-info?versioned=true.

[58] G. Chen, W. G. Di Wu, Y. Cao et al., "Clinical and immunologic features in severe and moderate forms of coronavirus disease 2019," 2020, https://www.medrxiv.org/content/10.1101/ 2020.02.16.20023903v1.

[59] B. E. Young, S. W. X. Ong, S. Kalimuddin et al., "Epidemiologic features and clinical course of patients infected with SARS-CoV-2 in Singapore," JAMA, vol. 323, no. 15, 2020.

[60] S.-Q. Deng and H.-J. Peng, "Characteristics of and public health responses to the coronavirus disease 2019 outbreak in China," Journal of Clinical Medicine, vol. 9, no. 2, p. 575, 2020.

[61] Y. Huang, M. Tu, S. Wang et al., "Clinical characteristics of laboratory confirmed positive cases of SARS-CoV-2 infection in Wuhan, China: A retrospective single center analysis," Travel medicine and infectious disease, vol. 4, article 101606, 2020.

[62] K. Liu, Y.-Y. Fang, Y. Deng et al., "Clinical characteristics of novel coronavirus cases in tertiary hospitals in Hubei Province," Chinese Medical Journal, vol. 133, no. 9, pp. 10251031, 2020.

[63] S. Tian, N. Hu, J. Lou et al., "Characteristics of COVID-19 infection in Beijing," Journal of Infection, vol. 80, no. 4, pp. 401-406, 2020.

[64] X.-W. Xu, X.-X. Wu, X.-G. Jiang et al., "Clinical findings in a group of patients infected with the 2019 novel coronavirus (SARS-Cov-2) outside of Wuhan, China: retrospective case series," BMJ, vol. 368, 2020. 